\title{
The depth distribution of Ostracoda from the Greenland Sea
}

\author{
ROBIN WHATLEY, ${ }^{1}$ MICHAEL EYNON ${ }^{2} \&$ ALICIA MOGUILEVSKY ${ }^{1}$ \\ ${ }^{1}$ Micropalaeontology Research Group, Institute of Earth Studies, University of Wales, Aberystwyth, UK. \\ ${ }^{2}$ Time Trax, Guildford, Surrey, UK. \begin{abstract}
Greenland shelf and slope were analysed for Ostracoda. The samples which range in depth from $274 \mathrm{~m}$ to $3355 \mathrm{~m}$, yielded a total of 52 species belonging to 25 genera. No less than 26 of the species also occur in the adjacent Scoresby Sund fjord complex. The fauna represents an interesting mixture of high latitude shallow water Arctic species and others known from bathyal and abyssal depths in the North Atlantic, including some pandemic deep sea species. Many species occur in shallower water here than in the North Atlantic due to the colder water. The fauna comprised of three associations (Shelf/Upper Slope; Slope: Lower Slope/Abyss). A marked faunal turnover occurs at the Upper Slope. The study raises questions concerning the constancy and universality of the relationship between certain ostracod species and water masses. J. Micropalaeontol. 17(1): 15-32, April 1998.
\end{abstract} \\ ABSTRACT - Sixteen box core samples of Recent sediment collected in three transects across the East
}

\section{INTRODUCTION}

The principal aims of this study are to investigate the bathymetrical distribution of benthonic Ostracoda in three transects from the outer shelf to the abyss and spanning depths from $265 \mathrm{~m}$ to $3555 \mathrm{~m}$ off the East Coast of Greenland. Other samples, from the Scoresby Sund Fjord system, ranging in depth from $270 \mathrm{~m}$ to $1280 \mathrm{~m}$ are considered elsewhere (Whatley et al., in press).

The samples were collected during September 1990 by the German research vessel R.V. Polarstern on cruise ARK VII3b, as part of the PONAM research project. This project (Late Cainozoic evolution of the POlar North Atlantic Margins) seeks to investigate the mechanisms involved in glacial/interglacial exchange with the aim of increasing our understanding of long term climatic change, land/shelf/ocean sediment budgets and ice/ocean mass balance.

Figure 1 shows the general area of the Greenland Sea and the east coast of Greenland, and gives the present day maximum extent of ice cover. Figure 2 gives the position of the sampling stations and also the bathymetry below $500 \mathrm{~m}$ offshore.

\section{METHODS}

The samples were collected between 31st August and 27th September 1990 , by a $0.5 \times 0.5 \times 0.5 \mathrm{~m}$ box-corer, recovering an average of $30-40 \mathrm{~cm}$ of undisturbed sediment from the surface of the sea bed (Solheim et al., 1991). From each box core, $60 \mathrm{~cm}^{3}$ of sediment was taken, preserved in buffered formalin and, in the laboratory, washed over a 200 mesh/inch $(75 \mu)$ sieve. The dry residue was passed through a nest of sieves, and the 30,60 and $100 \mathrm{mesh} / \mathrm{inch}(500,250,150 \mu)$ fractions were examined and all the Ostracoda picked out. Location, depth and ecological data for each sample, are given in the Appendix.

\section{OCEANOGRAPHY}

The Greenland and Norwegian seas are characterized by a complex exchange and mixing of Polar and Subtropical water masses and by the formation of deep, dense water. The region is controlled by submarine ridges, bounded to the North by the Nansen Ridge and to the South by the relatively shallow $(600$ $800 \mathrm{~m})$ Greenland-Iceland Ridge and Iceland-Shetland Ridge and these ridges are important constraints upon circulation.
Among the important oceanographical studies of the region are those by Aagaard (1968, 1981, 1982); Aagaard \& Coachman (1969); Worthington (1970); Peterson \& Rooth (1976); Aagaard et al. (1981); Aagaard et al. (1985) and Bourke et al. (1987).

A reduced flow of water passes through the Northern Gateway of the Fram Strait, the Southern Gateway of the Denmark Strait and the region between Iceland and Norway. The exiting water which cascades over the Southern Gateway forms a very large proportion of the North Atlantic Deep Water (NADW). Dingle \& Lord (1990) demonstrated the importance of this water mass to the distribution of benthonic Ostracoda in the Atlantic.

The Greenland Basin has depths greater than $4000 \mathrm{~m}$. The Continental Shelf off East Greenland is deep with the slope break occurring at some $500 \mathrm{~m}$; it is widest to the North and decreases in width towards the South.

The Arctic seas are regarded as mediterranean type basins because of their enclosed nature and from the input of light surface waters which balances the southward outflow of deep, dense water. This results in the density of the water of the Greenland Sea being among the densest in the world. Worthington (1970) attributes the high density of the water as being due to its low temperature which is brought about by high latitude and heat loss to the atmosphere. The salinity is generally low, being between $34 \%$ and $35 \%$.

There has been much confusion and imperfect understanding of the physical mechanisms at work in the GreenlandNorwegian Sea, which mainly stems from the problem of renewal rates of deep waters and where convective mixing and the amount of 'new' water being added to the deeper layers cannot be easily determined (Peterson \& Rooth, 1976). Aagaard (1982) compared the major process of the Greenland/Norwegian Sea to a 'giant snorkel', which draws down the upper layers of water into the abyss and through into the Arctic, forming the deep polar waters.

Details of the circulation and water mass budgets are given by Aagaard et al. (1985) who also discuss the water mass structure of the Arctic seas. They divided the water column into four water masses, largely on the basis of increased density with depth, and show that the boundaries between the various water masses occur at different depths throughout the Arctic basins as 


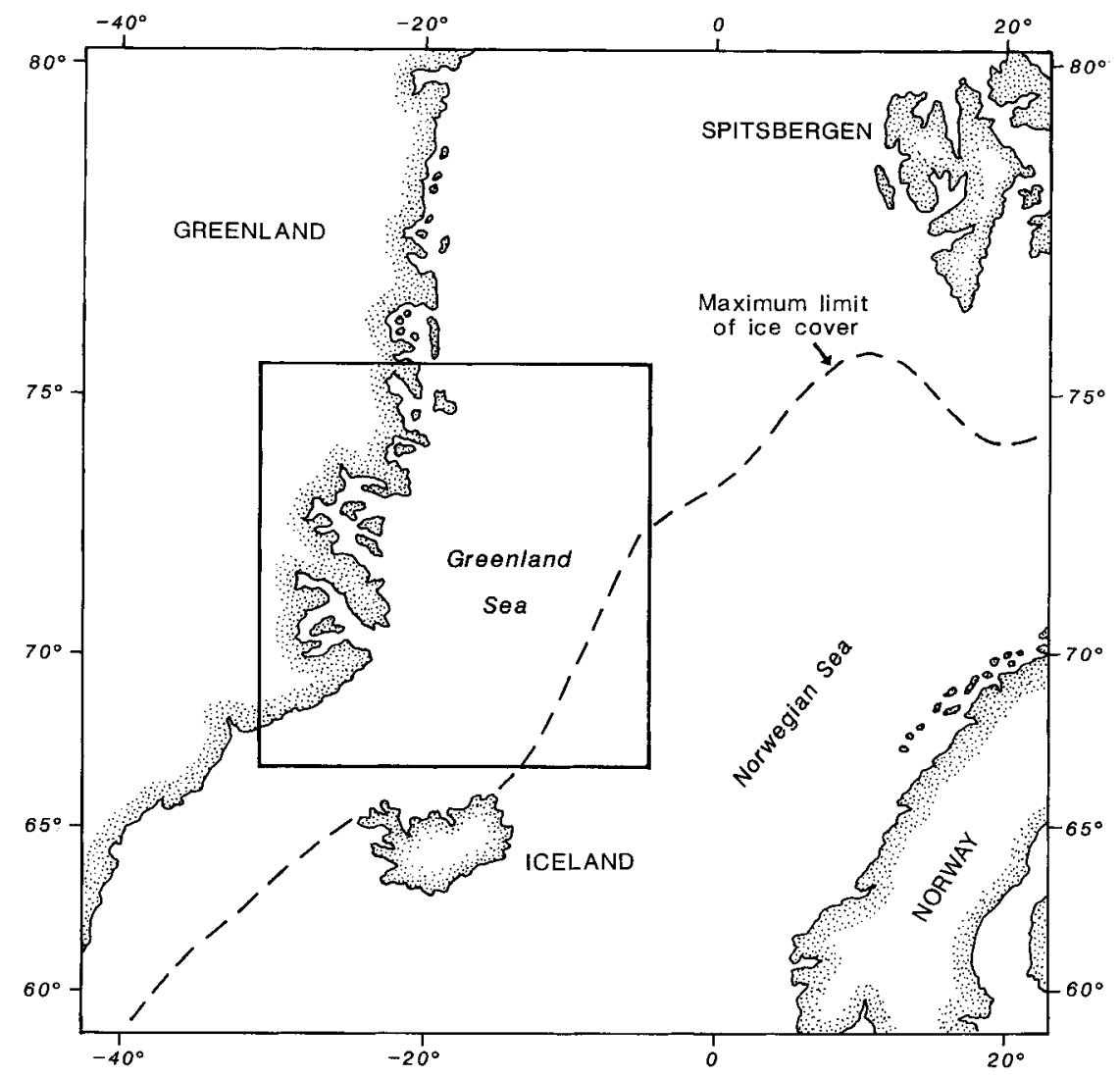

Fig. 1. The study area showing the maximum winter ice cover in the Greenland and Norwegian seas.

a consequence of them being greatly influenced by submarine topographic features:

(1) The North Atlantic Drift (NAD) (surface waters). The surface waters of the Greenland Sea lie above the density level of 27.9. These waters are warmest in the Norwegian Sea $\left(>1^{\circ} \mathrm{C}\right)$ and relatively highly saline $(34.5 \%)$. They originate in the Atlantic as part of the NAD and, while much thicker in the Norwegian Sea $(<200 \mathrm{~m})$ and Iceland Sea $(<150 \mathrm{~m})$, here the surface water is usually only some $50 \mathrm{~m}$ thick and characterized by relatively high salinity $(>35 \%)$ and temperature $\left(>1^{\circ} \mathrm{C}\right)$.

(2) Arctic Intermediate Water (AIW). This originates from the Iceland and Greenland gyres, occurs close to the surface, is well oxygenated and cold. In the Iceland and Norwegian seas, this is the primary water body to flow over the Faeroes Bank; in the latter sea, these intermediate waters are contaminated by deeper waters by upwelling. Peterson and Rooth (1976) interpreted the hydrogen isotope data, indicating that these waters have a short residence time in the Greenland Norwegian Sea Area (GNSA). They concluded that the overflow from the Norwegian Sea into the Atlantic (forming the NADW), through the Southern Gateways originates above the permanent pycnocline and, therefore, these dense overflow waters which cascade over the Greenland-Scotland Ridge are separate from the Norwegian and Greenland sea Deep Waters.

(3) The Greenland Sea Deep Water (GSDW). The NAD enters through the Southern Gateway but in the Norwegian Sea, the surface waters are too warm to sink, although the salinities are great enough to allow this. It is not until it reaches the Greenland Sea that the cooling of the surface waters by the atmosphere and ice cover, reduces its temperature enough to allow it to sink into the basins. Peterson \& Rooth (1976) estimated from the hydrogen isotope decay rate that some 30 years was required for the deep convective mixing of the NAD water in the Greenland Sea. Since some of the basins are $3000 \mathrm{~m}$ in depth, this suggests that some $100 \mathrm{~m}$ of the surface waters is mixed down annually.

Aagaard et al. (1985) divided the water column of the region by the increase in density, in this very dense water. In the Greenland Sea, the boundary between intermediate and deep water, the 32.785 density level, occurs at c. $200 \mathrm{~m}$, while in the Iceland Sea it occurs at $c .650 \mathrm{~m}$. The GSDW extends down to some $900 \mathrm{~m}$ where, below the 37.445 density level, true Arctic deep water occurs. The GSDW is characterized by temperatures of $<1^{\circ} \mathrm{C}$ and salinities of 34.88 to $34.90 \%$, with the Norwegian Sea Deep Water (NSDW) being slightly warmer and more saline. The Eurasian Basin Deep Water (EBDW) of the Arctic Ocean is even warmer and saltier, and, with the Lomonosov Ridge restricting the mixing of the EBDW and the Canadian Basin Deep Water (CBDW), this results in the latter water mass being the most saline and the warmest of the Arctic deep waters (Aargaard et al., 1985).

(4) The Eurasian Basin Deep Water (EBDW). The input of 


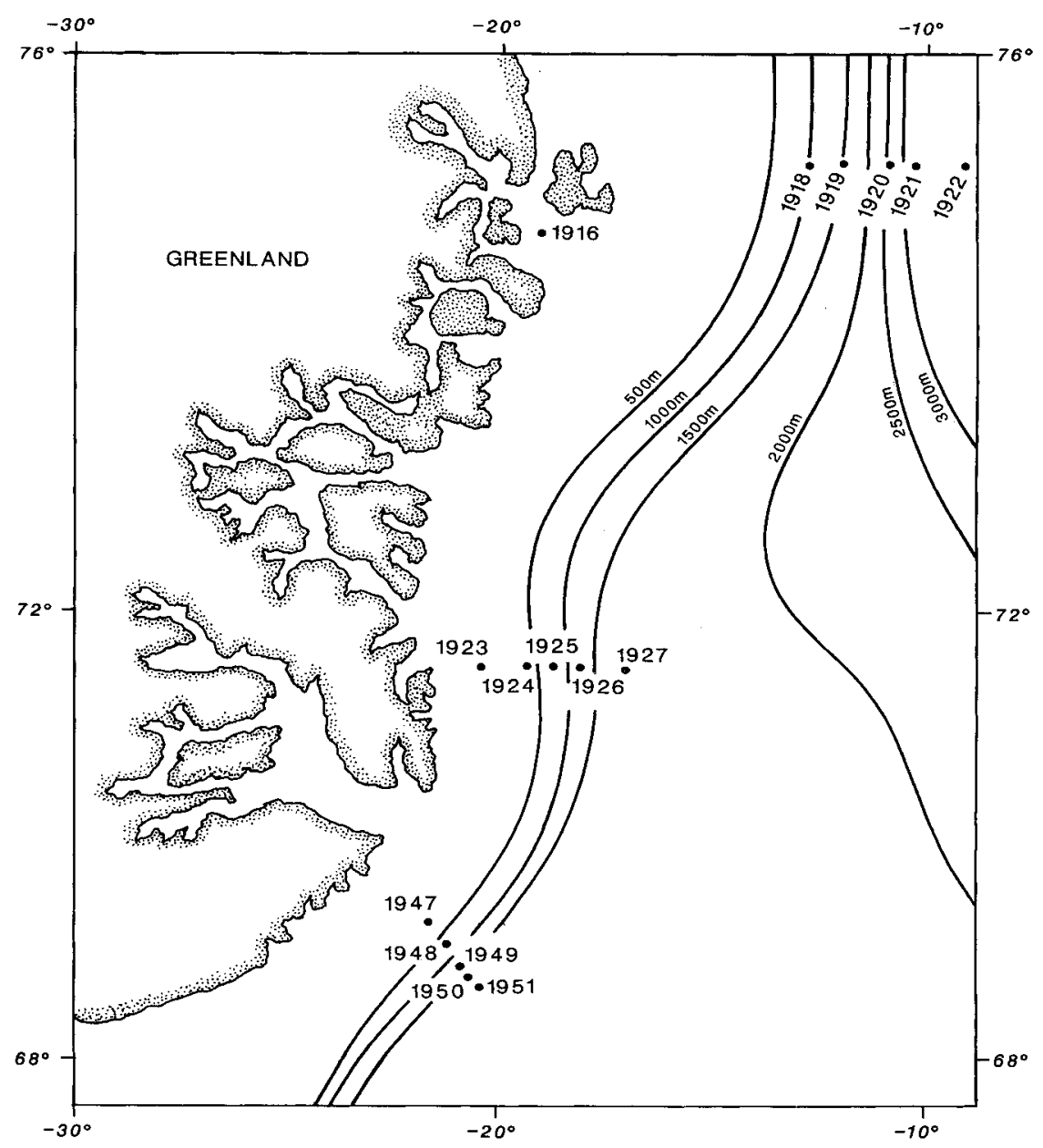

Fig. 2. The location of the sampling stations and the bathymetry of the Greenland Sea.

this water into the Greenland Sea was discovered by Aargaard et al. (1985) when they recorded the salinities of the water column in a transect away from the coast of East Greenland This is water from the floor of the Arctic Ocean which spills over the Fram Straits into the Greenland Sea. It has a temperature of $0.95^{\circ} \mathrm{C}$ and a salinity of $34.93 \%$, and is characteristically high in silica.

The dissolved oxygen content of the Norwegian and Greenland seas is very high throughout the water column and is among the most highly oxygenated water in the world with values in the Greenland Sea between $7.82 \mathrm{ml}^{-1}$ and $7.1911^{-1}$. These high levels are the result of low productivity, relatively low nutrients and the sinking of the NAD in the Greenland Sea. The oxygen minimum zone occurs here between $800 \mathrm{~m}$ and $1200 \mathrm{~m}$, with oxygen levels of $7.2 \mathrm{mll}^{-1}$; oxygen levels of $7.4 \mathrm{ml}^{-1}$ obtain below $2000 \mathrm{~m}$.

Useful diagrams, showing the water mass structure of the Greenland Sea and the physico-chemistry of its components, are to be found in Aagaard (1981), Aagaard et al. (1985) and Belanger \& Streeter (1980). Some additional details can be found in Eynon (unpublished MSc Thesis, University of Wales, Aberystwyth).

\section{Nutrients}

The Greenland Sea is one of rather low productivity because of the low temperature and ice cover which restrict solar energy input into the system. Nutrient levels, through the water column, are generally characterized by low concentrations in the surface layers (consumed by plants) and higher values at lower depths (concentration due to the death and decay of organisms). In the Greenland Sea, nutrients are fairly constant throughout the water column. Belanger \& Streeter (1980), show that, through the column, phosphates are constant, with a slight peak below the Oxygen Minimum Zone (at $1200 \mathrm{~m}$ ), silicates tend to increase to $c .1000 \mathrm{~m}$ before becoming relatively constant and nitrates have their maximum between $500 \mathrm{~m}$ and $1500 \mathrm{~m}$, before decreasing gradually with greater depth.

\section{Recent Sediments}

Sands, clays and muds prevail on the shelf being increasingly contaminated by ice rafted pebbles and boulders towards the coast (Vogt et al., 1981). In some areas substantial gouging by icebergs has taken place. 


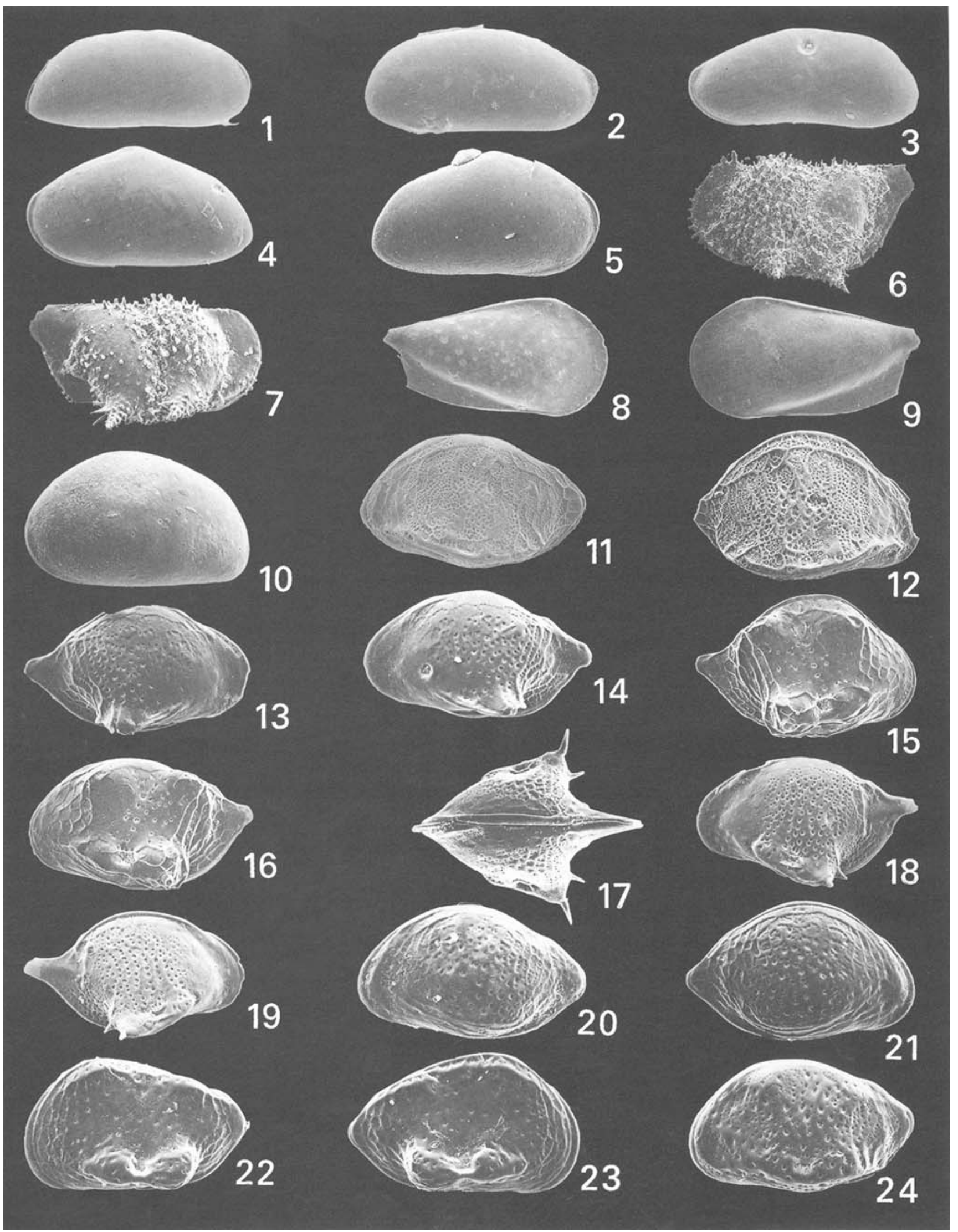




\section{THE OSTRACODA}

\section{Previous studies on benthonic Ostracoda from Greenland and the} Arctic

Early taxonomic studies were by Brady (1866) on the fauna from West Greenland and by the same author from the Davis Straits (1868) and the Gulf of St Lawrence (1870). Norman (1877) listed the ostracods collected by H.M.S. Valorous from West Greenland in 1875 and Brady (1878) recorded the ostracods to the North of Baffin Bay from samples collected by H.M. Ships Alert and Discovery. Brady \& Norman (1889) documented the podocopid ostracods collected off Northwest Greenland and in the Davis Strait, and combined their recordings with previously published notes on the fauna of the region.

All existing published works on the Ostracoda of East Greenland are based on samples collected from depths of less than $250 \mathrm{~m}$. Sars (1909) recorded the total Crustacea collected by the 2nd Norwegian Arctic Expedition (1898-1902) in the Fram Strait. Stephensen (1913) and Skogsberg (1920) recorded the shallow marine ostracods from between $68^{\circ} \mathrm{N}$ and $76^{\circ} \mathrm{N}$ off the East Greenland coast and, in 1939 Stephensen listed the ostracods encountered in Icelandic waters.

Hazel $(1967,1970)$ studied the ostracods between Cape Stosch, (Latitude $74^{\circ} 04^{\prime} \mathrm{N}$; Longitude $21^{\circ} 45^{\prime} \mathrm{W}$ ) from a depth of $7 \mathrm{fm}$ and Clavering Island (Latitude $74^{\circ} 15^{\prime} \mathrm{N}$; Longitude $21^{\circ} 00^{\prime} \mathrm{W}$ ) at $50 \mathrm{fm}$ as part of his study of the distribution of ostracods along the North American seaboard. Neale and Howe (1975) recorded the ostracods from Russian Harbour, Novaya Zemlya and also from Shannon Island (Latitude $75^{\circ} 20^{\prime} \mathrm{N}$; Longitude $19^{\circ} 00^{\prime} \mathrm{E}$ ) at $11 \mathrm{fm}$ and the H.M.S. Vidal Station 46 (Latitude $75^{\circ} 11,2^{\prime} \mathrm{N}$; Longitude $22^{\circ} 14^{\prime} \mathrm{E}$ ) at $7 \mathrm{fm}$.

More recently, Hawley (1980, unpublished MSc Thesis, Aberystwyth) studied the shallow water fauna of Lysefjord in Southwest Greenland, Whatley (1982) listed the littoral and immediate sublittoral ostracods from Sisimiut in Western Greenland, and Penney (1989) reported on the fauna from Ikerssuak, Southwest Greenland. Whatley \& Eynon (1996) describe three new species of Cytheropteron and one of Eucytherura from East Greenland and Whatley et al. (1996) discuss the fauna from the Scoresby Sund Fjord complex, East Greenland. Hartmann (1992, 1993, 1994) has described the Recent and subfossil Ostracoda of the Liefdejords in Spitzbergen.

A number of previous studies on late Cainozoic cold water Ostracoda from Europe, North America and Greenland are relevant to this study. In Europe, Brady et al. (1874) described many species from the British Quaternary which now live in the Arctic. Lord (1980) described an important fauna from the Sandness Clay of Norway and Penney (1990) from the North
Sea.

In North America, Benson et al. (1983) demonstrated the distribution and biofacies of Ostracoda from the Newfoundland slope and rise, and Cronin $(1979,1980)$ described the Pleistocene ostracod faunas from the southeastern Atlantic Coastal Plain and the St Lawrence Lowlands, respectively, and in the Greenland Sea area, Malz (pers. comm.) described the very poor fauna recovered from the Cainozoic of ODP Leg 104 on the Voting Platform off Norway, and Whatley (pers. obs.) recovered very few ostracods from the late Cainozoic of ODP Leg 151 in the region of the Fram Strait. Brouwers et al. (1991) documented the fauna of the Pliocene Kab Kobenhavn Formation, northern Greenland. Cronin (1991) described an essentially warm water Pliocene fauna from Tjornes, Iceland, and Cronin et al. (1994) discussed Quaternary palaeoceanography based on the Ostracoda of the deep Arctic Ocean.

Modern studies on the deep water faunas of the North Atlantic include those by Whatley (1993), Whatley and Coles (1987, 1990), Coles (1990) and Coles et al. (1990).

\section{The Greenland Sea fauna}

The species encountered in the present study are listed below. Those marked with an asterisk also occur in the adjacent Scoresby Sund Fjord complex (Whatley et al., 1996). All the species are illustrated in Plates 1-3, and the catalogue numbers refer to the Eynon Collection in the Micropalaeontology Museum at Aberystwyth, where the specimens are housed.

Acetabulastoma hyperborea Schornikov, 1970

* Argilloecia conoidea Sars, 1923

* Argilloecia cylindrica Sars, 1923

Baffinicythere howei Hazel, 1967

Bythocythere scaberrima (Brady, 1886).

* Cluthia cluthae Brady, Crosskey \& Robertson, 1874

*Cytherois pusilla Sars, 1928

*Cytheropteron arcticum Neale \& Howe, 1973

* Cytheropteron carolinae Whatley \& Coles, 1987

*Cytheropteron groenlandicum Whatley \& Eynon, 1996

*Cytheropteron hamatum Sars, 1869

* Cytheropteron inflatum Brady, Crosskey \& Robertson, 1874

*Cytheropteron neali Cronin, 1981

*Cytheropteron nodosum Brady, 1868

*Cytheropteron porterae Whatley \& Coles 1987

* Cytheropteron pseudoinflatum Whatley \& Eynon, 1996

* Cytheropteron pyramidale Brady, 1868

* Cytheropteron sedovi Schneider, 1969

*Cytheropteron scoresbyi Whatley \& Eynon, 1996

Cytheropteron syntomoalatum Whatley \& Masson, 1979

* Cytheropteron testudo Sars, 1869

\section{Explanation of Plate 1}

All external lateral views unless otherwise stated. fig. 1. Argilloecia conoidea Sars, 1923. Female RV, ME/1/P3, $\times 62.5$. figs 2, 3. Argilloecia cylindrica Sars, 1923; fig. 2. RV, ME/2/T, $\times 76$; fig. 3, LV, ME/2 /P1, ×76. figs 4, 5. Propontocypris trigonella (Sars, 1866); fig. 4, LV, ME/4/T, $\times 93$; fig. 5, RV, $\mathrm{ME} / 4 / \mathrm{Pl}$, $\times 95$. figs 6, 7. Bythoceratina scaberrima (Brady, 1886); fig. 6, LV, ME $/ 6 / \mathrm{T}, \times 42$; fig. 7, RV, ME/6/P1, $\times 54.5$. figs 8, 9. Pseudocythere caudata Sars, 1866; fig. 8, RV, ME/7/PI, $\times 55.5$; fig. 9, LV, ME/7/T, $\times 53$. fig. 10. Haplocytheridea bradyi (Norman, 1865); LV, ME $/ 8 / \mathrm{T}, \times 58$. figs 11, 12. Cytheropteron arcticum Neale \& Howe, 1973; fig. $11, \mathrm{LV}, \mathrm{ME} / 21 / \mathrm{T}, \times 85$; fig. $12, \mathrm{RV}, \mathrm{ME} / 21 / \mathrm{P} 1$, $\times 74$. figs 13, 14. Cytheropteron carolinae, Whatley \& Coles, 1987; fig. 13, RV, ME/22/T, $\times 85$; fig. 14, LV, ME/22/P1, $\times 85.5$. figs 15, 16. Cytheropteron groenlandicum Whatley \& Eynon, 1996; fig. 15, holotype RV, BMNH 1992.603, $\times 72$; fig. 16, paratype LV, BMNH 1992.604/1, $\times 72$. figs 17-19. Cytheropteron hamatum Sars, 1869; fig. 17, carapace dorsal view, ME/24/P2, $\times 105$; fig. 18, LV, ME/24/T, $\times 75.5$; fig. $19, \mathrm{RV}, \mathrm{ME} / 24 / \mathrm{P} 1, \times 70$. figs 20, 21. Cytheropteron inflatum Brady, Crosskey \& Robertson, 1874; fig. 20, LV, ME/25/T, $\times 91$; fig. 21, RV, ME/25/P1, ×76. figs 22, 23. Cytheropteron neali Cronin, 1981; fig. 22, LV (Juv.), ME/27/T, ×85.5; fig. 23, RV (Juv.), ME/27/P1, ×97.5. fig. 24. Cytheropteron nodosum Brady, 1868; LV (Juv.), ME/28/T, $\times 97.5$. 





${ }^{*}$ Cytheropteron vespertilio (Reuss, 1850).

*Eucythere argus Sars, 1866

*Eucythere sp. A

Eucythere sp. B

Eucytherura delineata Whatley \& Eynon, 1996

Finmarchinella barentzovensis Mandelstam, 1957

Hemicytherura clathrata (Sars, 1866).

Henryhowella dasyderma (Brady, 1880).

* Krithe glacialis Brady, Crosskey \& Robertson, 1874

Krithe minima Coles, Whatley \& Moguilevsky, 1994

Krithe sp. A

Krithe sp. B

Krithe sp. C

Krithe sp. D

Krithe sp E

Krithe sp. F

* Microcythere sp.

Muellerina abyssicola (Sars, 1865).

Nannocythere sp.

* Swainocythere nanseni (Joy \& Clark, 1977).

Paracytherois flexuosum Müller, 1894

Paradoxostoma productum Brady \& Norman, 1889

Polycope areolata Sars, 1923

Polycope clathrata Joy \& Clark, 1977

*Polycope orbicularis Sars, 1866

Propontocypris sp.

* Pseudocythere caudata Sars, 1866

Rabilimis mirabilis (Brady, 1868).

Haplocytheridea bradii (Norman, 1865)

Semicytherura affinis (Sars, 1865)

*Thaerocythere crenulata (Sars, 1865)

This fauna represents an interesting mixture of high latitude shallow water Arctic species and those known from bathyal and abyssal depths in the North Atlantic, which include some species which are virtually world wide (the major exception being the Arctic Ocean) at these depths. Since it is temperature, a secondary function of depth which, except in most unusual circumstances, is the primary controlling feature on the bathymetrical distribution of all marine benthos, at such high latitudes with such low temperatures, it is not surprising to encounter some considerable difference in the depth distribution of ostracod species between the Greenland Sea and further south in the North Atlantic, although this has not been previously documented.

For example, six species whose depth range extends below
$1000 \mathrm{~m}$ and which are common to the North Atlantic (data from the compilation of Dingle Lord, 1990) and the area of the present study in the Greenland Sea, are seen to occur in shallower water in the latter area. Two of the species (Cytheropteron porterae and $C$. testudo actually occur within the adjacent Scoresby Sund Fjord system on the East coast of Greenland at depths between 277 and $1262 \mathrm{~m}$ (Whatley et al., 1996). The implications for the recognition of palaeo-watermass using ostracods is obvious. The comparative depth distribution (in $\mathrm{m}$ ) of the six species in the two areas is given in Table 1.

Table 1. Differential depth distribution of six ostracod species in their dual occurrences in the Greenland Sea and the North Atlantic Ocean.

\begin{tabular}{lll}
\hline Species & North Atlantic & Greenland Sea \\
\hline Cytheropteron testudo & $1380-3526$ & $256-1090$ \\
Cytheropteron porterae & $2417-3884$ & $256-1091$ \\
Cytheropteron syntomoalatum & $2417-3884$ & $812-1470$ \\
Bythoceratina scaberrima & $3427-4780$ & $1090-1927$ \\
Cytheropteron carolinae & $3022-3427$ & $812-3065$ \\
Argilloecia conoidea & $400-3210$ & $377-3065$ \\
\hline
\end{tabular}

The relationship of the fauna to depth is shown in Tables 2 and 3 which plot the species in depth order by first appearance of upper and lower limit, respectively. These two tables also show at what levels various species are represented by live individuals. Figures 3 and 4 depict graphically the appearance and disappearance of species with increasing depth, respectively.

The depth ranges of the ostracods plotted in Tables 2 and 3 show that certain taxa are restricted to the shelf/upper slope, the slope and the lower slope/Greenland Basin abyss. Some species, however, range across the entire bathymetry of the East Greenland continental margin. The various depth categories of these associations are given below:

The shelf/upper slope association

\begin{tabular}{ll}
\hline Species & Depth range (m) \\
\hline Krithe glacialis & $274-279$ \\
Cluthia cluthae & $274-651$ \\
Cytheropteron arcticum & $274-651$ \\
Cytheropteron inflatum & $274-651$ \\
Thaerocythere crenulata & $274-651$ \\
Cytheropteron sedovi & $279-812$ \\
Cytheropteron groenlandicum & $651-1090$
\end{tabular}

\section{Explanation of Plate 2}

All external lateral views unless otherwise stated. figs 1, 2. Cytheropteron porterae Whatley \& Coles, 1987; fig. 1, LV, ME/29/T, $\times 61 ;$ fig. 2, RV, ME/ 29/P1, $\times 59.5$. figs 3-5. Cytheropteron pyramidale Brady, 1868; fig. 3, LV, ME/30/T, $\times 66.5$; fig. 4, RV, ME/30/P1, $\times 67.5$; fig. 5, carapace dorsal view, $\mathrm{ME} / 30 / \mathrm{P} 2, \times 69$. figs 6, 10. Cytheropteron scoresby Whatley \& Eynon, 1996; fig. 6, carapace dorsal view (Juv. A-2), paratype BMNH, 1992.609, $\times 77$; fig. 10, RV, paratype, BMNH 1992.608, $\times 77$. figs 7-9. Cytheropteron pseudoinflatum Whatley \& Eynon, 1996; fig. 7, RV, holotype, BMNH 1992, $\times 79$; fig. 8, carapace, paratype, BMNH 1992.603/3, $\times 79$; fig. 9, carapace, paratype BMNH 1992.603/3, $\times 75.5$. figs 11, 12. Cytheropteron sedovi Schneider, 1969; fig 11, LV, ME/33/T, $\times 78.5 ;$ fig. 12, RV, ME/33/P1, ×80. fig. 13. Cytheropteron syntomoalatum Whatley \& Masson, 1979; RV, ME/ $33 / \mathrm{P} 1, \times 114$. figs 14, 15. Cytheropteron testudo Sars, 1869; fig. 14, LV, ME $/ 36 / \mathrm{T}, \times 80$; fig. $15, \mathrm{RV}, \mathrm{Me} / 36 / \mathrm{P} 1, \times 83$. figs 16, 17. Cytheropteron vespertilio (Reuss, 1850); fig. 16, RV, ME/37/P1, ×52.5; fig. 17, LV, ME/37/T, $\times 51$. fig. 18. Hemicytherura clathrata (Sars, 1866); LV (Juv.), ME/38/ $\mathrm{T}, \times 124$. fig. 19. Semicytherura affinis (Sars, 1865) broken LV (Juv.), ME/40/T, $\times 52.5$. figs 20, 21. Eucytherura delineata Whatley \& Eynon, 1996; fig. 20, LV, holotype BMNH 1992.612, ×95; fig. 21, RV, paratype BMNH 1992.613, $\times 94$. fig. 22. Eucythere argus Sars, 1866; male RV, ME/10/T, $\times 45$. figs 23, 24. Eucythere sp A; fig. 23, LV, ME/10/T, $\times 94$; fig. 24, RV, ME/10/P1, $\times 100$. fig. 25. Eucythere sp B, RV (Juv.), ME/11/P1, $\times 105$. 


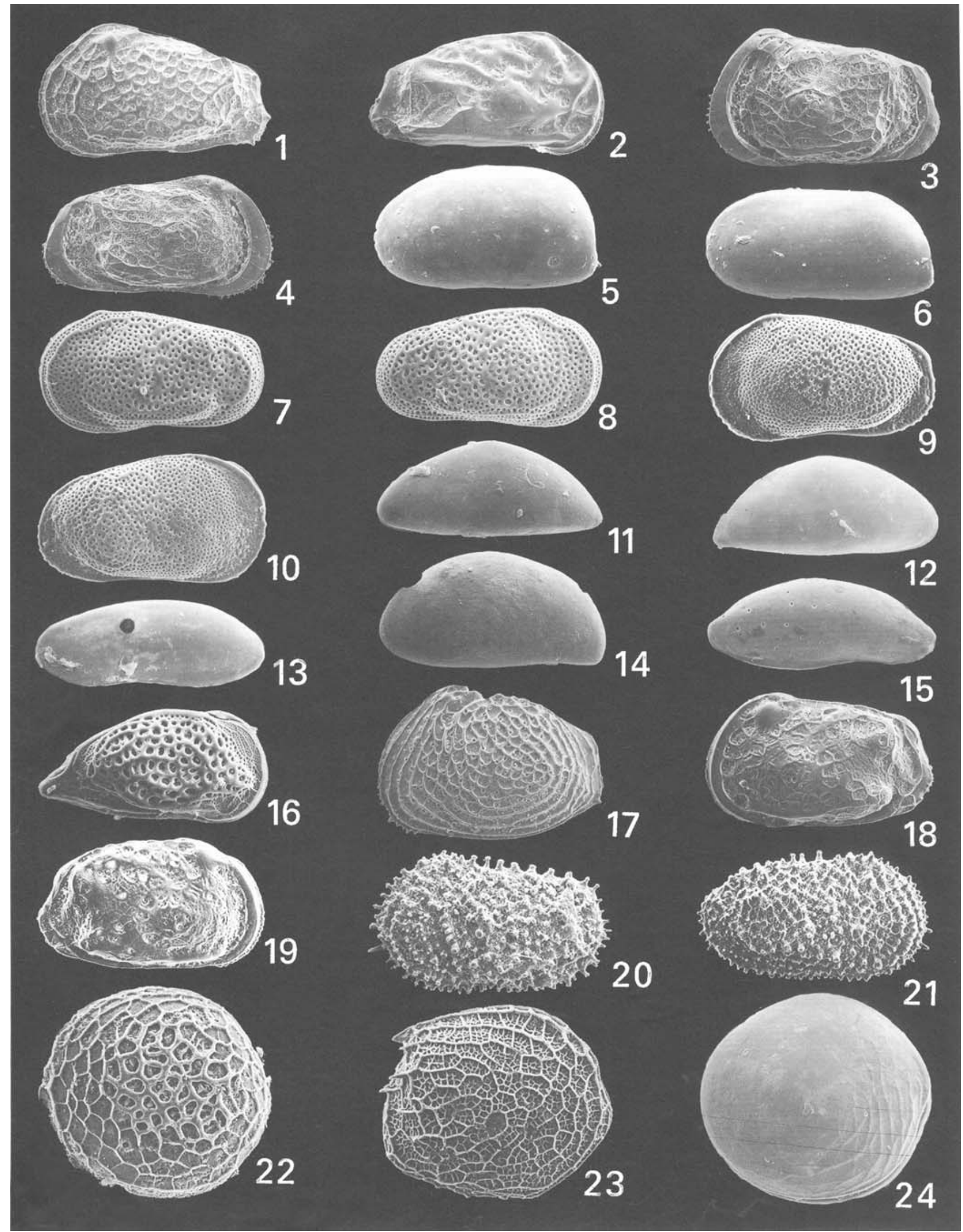




$\begin{array}{ll}\text { Cytheropteron testudo } & 274-1090 \\ \text { Cytheropteron pyramidale } & 256-1090 \\ \text { Muellerina abyssicola } & 279-1090 \\ \text { Cytheropteron porterae } & 256-1091 \\ \text { Eucytherura delineata } & 651-1090\end{array}$

The slope association

\begin{tabular}{ll} 
Species & Depth range (m) \\
\hline Krithe sp. B. & $812-1470$ \\
Cytheropteron syntomoalatum & $812-1470$ \\
Argilloecia cylindrica & $279-1735$ \\
Bythoceratina scaberrima & $1090-1927$ \\
Nannocythere sp. & $1090-1927$ \\
Krithe minima & $1091-2687$ \\
Henryhowella dasyderma & $1735-2687$ \\
\hline
\end{tabular}

Slope and abyssal association

\begin{tabular}{ll}
\hline Species & Depth range \\
\hline Cytheropteron carolinae & $812-3065$ \\
Krithe sp. A. & $1464-3065$ \\
Cytheropteron vespertilio & $651-3355$ \\
Cytheropteron hamatum & $651-3355$ \\
Cytheropteron scoresbyi & $1090-3355$ \\
\hline
\end{tabular}

The taxa whose depth ranges embrace the entire or virtually the entire bathymetry sampled are:

\begin{tabular}{ll}
\hline Species & Depth range \\
\hline Paracytherois flexuosum & $256-2687$ \\
Polycope orbicularis & $279-2687$ \\
Pseudocythere caudata & $274-3065$ \\
Argilloecia conoidea & $377-3065$ \\
\hline
\end{tabular}

\section{Faunal turnover}

The Greenland Sea is characterized by a faunal turnover which occurs in the depth range of the upper slope. This is shown in Tables 2 and 3 of species distribution by depth, arranged by upper and lower limit, respectively, and by Figs 3 and 4 showing the appearances and disappearances of species against depth.
They show that there is an increase in both the number of species disappearing and appearing between the depths of $600 \mathrm{~m}$ and $1100 \mathrm{~m}$, which is exhibited in two major peaks at 650 and $1090 \mathrm{~m}$ respectively. The majority of taxa which inhabit the continental slope first appear on the upper slope, between $c$. $600 \mathrm{~m}$ and $1100 \mathrm{~m}$. Only seven species which occur on the shelf, range through to the middle and lower slope. This is probably to some extent a function of the fact that the thermocline, which is such a formidable ecological barrier in lower latitudes, is much less important in the Greenland Sea. A further peak in the number of disappearing taxa occurs at 2687 (Figs 3 and 4) but here, unlike the upper slope peak, the fauna is not replaced by newly appearing taxa.

The ostracod counts for each sample when converted to percentage data are shown in Fig. 5. This illustrates the upper slope faunal turnover and also shows that possibly the most important correlative is the oxygen minimum zone. Figure 6. represents, in depth order of the samples, the abundance, the species diversity, the number of live specimens recovered, the percentage of live specimens and generic diversity across the East Greenland continental margin. Table 4 gives most of this data numerically. The greatest number of specimens was recovered from the continental slope, although the lowest number of specimens was also recorded from this depth zone. The greatest number and percentage of live specimens were from the shelf and upper slope samples, above $651 \mathrm{~m}$, while a localized peak of live specimens occurs on the lower slope at $1735 \mathrm{~m}$.

Generic and specific diversity shows a decline with increasing depth, although some shelf samples were of very low diversity. Diversity remains reasonably high, but fluctuating, on the continental slope, but decreases into the abyss.

\section{THE KRITHE PROBLEM}

Peypouquet $(1975,1977,1979)$ formulated the hypothesis that there exists a relationship between the size and shape of the anterior vestibulum of Krithe species and the amount of dissolved oxygen in the water. This led to the widespread belief that Krithe with large vestibula corresponded to areas depauperate in oxygen and vice versa. This has been considered in some detail and systematically rejected by Whatley Zhao (1993) and Coles et al. (1994). In the Greenland Sea, where high dissolved oxygen levels are relatively constant with depth, the unnamed Krithe species include two with large, two with medium sized and 3 with small vestibula which occur together along the continental rise and slope and, therefore, no relationship between vestibulum size and shape and oxygen levels was found (Figs 7 and 8).

\section{Explanation of Plate 3}

All external lateral views. fig. 1. Baffinicythere howeii Hazel, 1967; LV, ME/41/T, $\times 54$. fig. 2. Finmarchinella barentzovoensis Mandelsatam, 1957; RV, $\mathrm{ME} / 43 / \mathrm{T}, \times 49$. figs 3, 4. Muellerina abyssicola (Sars, 1865); fig. 3, female LV, ME $/ 44 / \mathrm{P} 2, \times 44.5$; fig. 4, male RV, ME $/ 44 / \mathrm{P} 1, \times 44$. figs 5, 6. Krithe glacialis Brady, Crosskey \& Robertson, 1874; fig. 5, female LV, ME/12/P2, $\times 54$; fig. 6, male RV, ME $/ 12 / \mathrm{T}$, $\times 51$. figs 7, 8. Cluthia cluthae Brady, Crosskey \& Robertson, 1874; fig. 7, female LV, ME/45/T, $\times 100$; fig. 8, male RV, ME $/ 45 / \mathrm{P} 1, \times 105$. figs 9, 10. Nannocythere sp; fig. 9, LV, ME/47/T1, $\times 109$; fig. $10, \mathrm{RV}, \mathrm{ME} / 47 / \mathrm{P} 1, \times 110$. figs 11, 12. Microcythere sp; fig. $11, \mathrm{LV}, \mathrm{ME} / 52 / \mathrm{T}, \times 133$; fig. 12 , $\mathrm{RV}, \mathrm{ME} / 52 / \mathrm{Pl}, \times 143$. fig. 13. Cytherois pusilla Sars, 1928; LV, ME/49/T, $\times 81.5$. fig. 14. Acetabulostoma hyperboreum (Scott, 1899); RV, ME/48/T, $\times 71$. fig. 15. Paracytherois flexuosum (Brady, 1867); RV, ME/50/T, $\times 50.5$. fig. 16. Swainocythere nanseni (Joy \& Clark, 1977); RV, ME/53/P1, ×149. fig. 17. Rabimilis mirabilis (Brady, 1868); LV, $\mathrm{ME} / 54 / \mathrm{T}, \times 32$. figs 18, 19. Thaerocythere crenulata (Sars, 1865); fig. 18, female LV, ME/56/T, $\times 42$; fig. 19, female RV, ME/56/P2, $\times 43$. figs 20, 21. Henryhowella dasyderma (Brady, 1880); fig. 20, female LV, ME $/ 55 / \mathrm{T}, \times 39 ;$ fig. 21 , male RV, ME/55/P1, $\times 38$. fig. 22. Polycope areolata Sars, 1923; LV, ME $/ 57 / \mathrm{T}, \times 172$. fig. 23. Polycope clathrata Joy \& Clark, 1977; RV, ME $/ 59 / \mathrm{T}, \times 115$. fig. 24. Polycope orbicularis Sars, $1866 ; \mathrm{RV}, \mathrm{ME} / 62 / \mathrm{T}, \times 81$. 
Table 2. The depth distribution of ostracod species in the Greenland Sea by upper limit:. xxxxx equals occurrence as dead specimens; LLLLL indicates the occurrence of live specimens of a species.

\begin{tabular}{|c|c|c|c|c|c|c|c|c|c|c|c|c|c|c|c|c|}
\hline $\begin{array}{l}\text { Sample } \\
\text { Depth (m) }\end{array}$ & $\begin{array}{l}1923 \\
256\end{array}$ & $\begin{array}{l}1916 \\
274\end{array}$ & $\begin{array}{l}1924 \\
279\end{array}$ & $\begin{array}{l}1947 \\
377\end{array}$ & $\begin{array}{l}1948 \\
651\end{array}$ & $\begin{array}{l}1925 \\
812\end{array}$ & $\begin{array}{l}1918 \\
1090\end{array}$ & $\begin{array}{l}1949 \\
1091\end{array}$ & $\begin{array}{l}1951 \\
1464\end{array}$ & $\begin{array}{l}1950 \\
1470\end{array}$ & $\begin{array}{l}1926 \\
1495\end{array}$ & $\begin{array}{l}1927 \\
1735\end{array}$ & $\begin{array}{l}1919 \\
1927\end{array}$ & $\begin{array}{l}1920 \\
2687\end{array}$ & $\begin{array}{l}1921 \\
3065\end{array}$ & $\begin{array}{l}1922 \\
3355\end{array}$ \\
\hline Cytheropteron neali & $\operatorname{xxxxx}$ & & & & & & & & & & & & & & & \\
\hline Eucythere sp. B. & $\operatorname{xxxxx}$ & & & & & & & & & & & & & & & \\
\hline Semicytherura affinis & LLLLL & & & & & & & & & & & & & & & \\
\hline Cytheropteron pyramidale & $\mathrm{xxxxx}$ & & & & $\operatorname{xxxxx}$ & & $\operatorname{xxxxx}$ & & & & & & & & & \\
\hline Cytheropteron porterae & $\operatorname{xxxxx}$ & & $\operatorname{xxxxx}$ & $\operatorname{xxxxx}$ & $\operatorname{xxxxx}$ & & & $\operatorname{xxxxx}$ & & & & & & & & \\
\hline Paracytherosis flexuosum & $\operatorname{xxxxx}$ & & LLLLL & $\operatorname{xxxxx}$ & & & $\operatorname{xxxxx}$ & & & $\mathrm{xxxxx}$ & & & $\operatorname{xxxxx}$ & LLLLL & & \\
\hline Cytheropteron nodosum & & $\operatorname{xxxxx}$ & & & & & & & & & & & & & & \\
\hline Eucythere sp. A & & $\mathrm{xxxxx}$ & & & & & & & & & & & & & & \\
\hline Rabilimis mirabilimis & & $\mathrm{xxxxx}$ & & & & & & & & & & & & & & \\
\hline Krithe glacialis & & LLLLL & LLLLL & & & & & & & & & & & & & \\
\hline Cluthia cluthae & & LLLLL & & LLLLL & LLLLL & & & & & & & & & & & \\
\hline Cytheropteron testudo & & LLLLL & LLLLL & LLLLL & LLLLL & $\mathrm{xxxxx}$ & $\operatorname{xxxxx}$ & & & & & & & & & \\
\hline Polycope orbicularis & & LLLLL & LLLLL & $\operatorname{xxxxx}$ & LLLIL & $\operatorname{xxxxx}$ & LLLLL & & & & & LLLLI. & LLLLL. & LLLLL & $\operatorname{xxxxx}$ & \\
\hline Pseudocythere caudata & & LLLLL & LLLLL & $\operatorname{xxxxx}$ & LLLLL & $\operatorname{XXXXX}$ & $\mathrm{xxxxx}$ & $\operatorname{xxxxx}$ & $\operatorname{xxxxx}$ & $\operatorname{xxxxx}$ & $\operatorname{xxxxx}$ & & LLLLL & $\mathrm{xxxxx}$ & $\operatorname{xxxxx}$ & \\
\hline Finmarchinella barentzovoensis & & & $\operatorname{xxxxx}$ & & & & & & & & & & & & & \\
\hline Cytheropteron arcticum & & & $\operatorname{xxxxx}$ & $\operatorname{xxxxx}$ & $\mathrm{xxxxx}$ & & & & & & & & & & & \\
\hline Cytheropteron inflatum & & & $\operatorname{xxxxx}$ & $\mathrm{xxxxx}$ & $\operatorname{xxxxx}$ & & & & & & & & & & & \\
\hline Thaerocythere crenulata & & & $\operatorname{xxxxx}$ & $\operatorname{xxxxx}$ & $\operatorname{xxxxx}$ & & & & & & & & & & & \\
\hline Cytheropteron sedovi & & & $\operatorname{xxxxx}$ & $\operatorname{xxxxx}$ & $\operatorname{xxxxx}$ & & & & & & & & & & & \\
\hline Muellerina abyssicola & & & $\mathrm{xxxxx}$ & LLLLL & LLLLL & & $\operatorname{xxxxx}$ & & & & & & & & & \\
\hline Argilloecia cylindrica & & & $\mathrm{xxxxx}$ & & $\operatorname{xxxxx}$ & $\mathrm{xxxxx}$ & LLLLL & & $\operatorname{xxxxx}$ & $\operatorname{xxxxx}$ & LLLLL & $\mathrm{xxxxx}$ & & & & \\
\hline Argilloecia conoidea & & & & LLLLL & LLLLL & $\operatorname{xxxXX}$ & LLLLL & $\operatorname{XxXXX}$ & & $\operatorname{xxxxx}$ & $\mathrm{xxxxx}$ & $\operatorname{xxxxx}$ & $\operatorname{xxxxx}$ & & $\operatorname{xxxxx}$ & \\
\hline Cytheropteron simplex & & & & & $\operatorname{xxxxx}$ & & & & & & & & & & & \\
\hline Krithe sp. D. & & & & & XXXXX & & & & & & & & & & & \\
\hline Polycope areolata & & & & & $\mathrm{xxxxx}$ & & & & & & & & & & & \\
\hline Cytheropteron groenlandicum & & & & & $\operatorname{xxxxx}$ & & $\operatorname{xxxxx}$ & & & & & & & & & \\
\hline Eucytherura delineata & & & & & $\operatorname{xxxxx}$ & $\operatorname{xxxxx}$ & $\mathrm{xxxxx}$ & & & & & & & & & \\
\hline Polycope clathrata & & & & & $\operatorname{xxxxx}$ & & & & & & & $\operatorname{xxxxx}$ & & & & \\
\hline Cytheropteron pseudoinflatum & & & & & $\operatorname{xxxxx}$ & $\operatorname{xxxxx}$ & & & $\mathrm{xxxxx}$ & $\operatorname{xxxxx}$ & $\operatorname{xxxxx}$ & & $\mathrm{xxxxx}$ & $\operatorname{xxxxx}$ & & \\
\hline Eucythere argus & & & & & $\operatorname{xxxxx}$ & & & & $\mathrm{xxxxx}$ & $\mathrm{xxxxx}$ & & $\operatorname{xxxxx}$ & & & $\operatorname{xxxxx}$ & \\
\hline Cytheropteron hamatum & & & & & $\operatorname{xxxxx}$ & $x \times x \times x$ & $\operatorname{xxxxx}$ & $\operatorname{xxxxx}$ & $\operatorname{xxxxx}$ & $\mathrm{xxxxx}$ & $\mathrm{xxxxx}$ & LLLLL & $\mathrm{Xxxxx}$ & $\operatorname{xxxxx}$ & LLLLL & $\operatorname{xxxxx}$ \\
\hline Cytheropteron vespertilio & & & & & $\operatorname{xxxxx}$ & $\operatorname{xxxxx}$ & $\operatorname{xxxxx}$ & $\operatorname{xxxxx}$ & $\mathrm{xxxxx}$ & $\operatorname{xxxxx}$ & $\operatorname{xxxxx}$ & $\operatorname{xxxxx}$ & $\mathrm{xxxxx}$ & $\mathrm{xxxxx}$ & $\mathrm{xxxxx}$ & $\operatorname{xxxxx}$ \\
\hline Cytheropteron syntomoalatum & & & & & & $\operatorname{xxxxx}$ & $\mathrm{xxxxx}$ & $\operatorname{xxxxx}$ & & $\mathrm{XXXXX}$ & & & & & & \\
\hline Krithe sp. $B$ & & & & & & LLLLL & LLLLL & $\operatorname{xxxxx}$ & $\mathrm{xxxxx}$ & $\operatorname{xxxxx}$ & & & & & & \\
\hline Cytheropteron carolinae & & & & & & $\mathrm{xxxxx}$ & $\mathrm{xxxxx}$ & $\operatorname{xxxxx}$ & & & & & $\mathrm{xxxxx}$ & $\operatorname{xxxxx}$ & & \\
\hline Acetabulastoma hyperborea & & & & & & & $\operatorname{xxxxx}$ & & & & & & & & & \\
\hline Paijenborchella sp. & & & & & & & $\operatorname{xxxxx}$ & & & & & & & & & \\
\hline Paradoxostoma productum & & & & & & & LLLLL & & & & & & & & & \\
\hline Cytherois pusilla & & & & & & & LLLLL & LLLLL & & & & & & & & \\
\hline Krithe sp. C & & & & & & & $\operatorname{xxxxx}$ & & $\operatorname{Xxxxx}$ & & & & & & & \\
\hline Microcythere sp. & & & & & & & LLLLL & & & LLLLL & & & & & & \\
\hline Bythoceratina scaberrima & & & & & & & $\mathrm{xxxxx}$ & $\operatorname{xxxxx}$ & & & & & $\mathrm{xxxxx}$ & & & \\
\hline Haplocytheridea bradii & & & & & & & $\mathrm{xxxxx}$ & & & & & & $\mathrm{xxxxx}$ & & & \\
\hline Nannocythere sp. & & & & & & & $\operatorname{xxxxx}$ & $\operatorname{xxxxx}$ & & $\operatorname{xxxxx}$ & $\operatorname{xxxxx}$ & $\operatorname{xxxxx}$ & $\mathrm{xxxxx}$ & & & \\
\hline Cytheropteron scoresbyi & & & & & & & $\operatorname{xxxxx}$ & & $\mathrm{Xxxxx}$ & & $\operatorname{xxxxx}$ & $\operatorname{xxxxx}$ & $\mathrm{xxxxx}$ & $\mathrm{xxxxx}$ & $\operatorname{xxxxx}$ & $\operatorname{xxxxx}$ \\
\hline Krithe sp. $F$ & & & & & & & & $\operatorname{xxxxx}$ & & & & LLLLL & & & & \\
\hline Krithe minima & & & & & & & & $\operatorname{xxxxx}$ & & & & $\mathrm{xxxxx}$ & & $\operatorname{xxxxx}$ & $x x x x x$ & \\
\hline Krithe sp. $A$. & & & & & & & & & $\mathrm{xxxxx}$ & $\mathrm{xxxxx}$ & $\mathrm{xxxxx}$ & LLLLL & $\mathrm{xxxxx}$ & $\mathrm{xxxxx}$ & $x \times x \times x$ & \\
\hline Propontocypris sp. & & & & & & & & & & $\mathrm{xxxxx}$ & & & & & & \\
\hline Krithe sp. E. & & & & & & & & & & & & $\operatorname{xxxxx}$ & & & & \\
\hline Henryhowella dasyderma & & & & & & & & & & & & $\operatorname{xxxxX}$ & & $\operatorname{xxxxx}$ & & \\
\hline Baffinicythere howei & & & & & & & & & & & & & & $\mathrm{xxxxx}$ & & \\
\hline Hemicytherura clathrata & & & & & & & & & & & & & & $\mathrm{xxxxx}$ & & \\
\hline
\end{tabular}

\section{The fauna of station 1918}

Maddocks \& Steineck (1987) and Steineck et al. (1990) considered the ostracod association living on experimental wood islands (between 1800 and $4000 \mathrm{~m}$ ) in various areas of the World Ocean. They discovered a unique assemblage of podocopid ostracods including the cytherurid genus $X y$ locythere [subsequently also encountered by Van Harten (1994) associated with vent faunas] and several species of Cytherois, Paradox- ostoma and Propontocypris all concentrated on the wood but absent from the surrounding sediment.

Station 1918, at a depth of $1090 \mathrm{~m}$, yielded the highest number of ostracod specimens from East Greenland, with Paradoxostoma, Cytherois and Propontocypris being well represented. Although no wood fragments were present in the sediment and Xylocythere was absent, the possibility of an adjacent wood parcel cannot be ruled out. 
Table 3. The depth distribution of ostracod species in the Greenland Sea by lower limit: xxxxx equals occurrence as dead specimens; LLLLL indicates the occurrence of live specimens of a species.

\begin{tabular}{|c|c|c|c|c|c|c|c|c|c|c|c|c|c|c|c|c|}
\hline $\begin{array}{l}\text { Sample } \\
\text { Depth (m) }\end{array}$ & $\begin{array}{l}1923 \\
256\end{array}$ & $\begin{array}{l}1916 \\
274\end{array}$ & $\begin{array}{l}1924 \\
279\end{array}$ & $\begin{array}{l}1947 \\
377\end{array}$ & $\begin{array}{l}1948 \\
651\end{array}$ & $\begin{array}{l}1925 \\
812\end{array}$ & $\begin{array}{l}1918 \\
1090\end{array}$ & $\begin{array}{l}1949 \\
1091\end{array}$ & $\begin{array}{l}1951 \\
1464\end{array}$ & $\begin{array}{l}1950 \\
1470\end{array}$ & $\begin{array}{l}1926 \\
1495\end{array}$ & $\begin{array}{l}1927 \\
1735\end{array}$ & $\begin{array}{l}1919 \\
1927\end{array}$ & $\begin{array}{l}1920 \\
2687\end{array}$ & $\begin{array}{l}1921 \\
3065\end{array}$ & $\begin{array}{l}1922 \\
3355\end{array}$ \\
\hline Cytheropteron scoresbyi & & & & & & & $\mathrm{xxxxx}$ & & $\mathrm{xxxxx}$ & & $\mathrm{xxxxx}$ & $\operatorname{xxxxx}$ & $\mathrm{xxxxx}$ & $\operatorname{XXXXX}$ & $\mathrm{XXXXX}$ & $\operatorname{xxxxx}$ \\
\hline Cytheropteron hamatum & & & & & $\operatorname{xxxxx}$ & $\operatorname{xxxxx}$ & $\operatorname{xxxxx}$ & $\operatorname{xxxxx}$ & $\operatorname{xxxxx}$ & $\mathrm{xxxxx}$ & $\operatorname{xxxxx}$ & $\operatorname{xxxxx}$ & LLLLL & $\operatorname{xxxxx}$ & $\operatorname{xxxxx}$ & $\operatorname{xxxxx}$ \\
\hline Cytheropteron vespertilio & & & & & $\mathrm{xxxxx}$ & $\operatorname{xxxxx}$ & $\operatorname{xxxxx}$ & $\mathrm{xxxxx}$ & $\operatorname{xxxxx}$ & $\operatorname{xxxxx}$ & $x \times x x x$ & $\operatorname{xxxxx}$ & $\operatorname{xxxxx}$ & $\operatorname{xxxxx}$ & $\operatorname{xxxxx}$ & $\operatorname{xxxxx}$ \\
\hline Krithe sp. $A$ & & & & & & & & & $\operatorname{xxxxx}$ & $\operatorname{xxxxx}$ & $\operatorname{xxxxx}$ & $\operatorname{xxxxx}$ & LLLLL & $\operatorname{xxxxx}$ & LLLLL & \\
\hline Eucythere argus & & & & & & & & & $\operatorname{xxxxx}$ & $\operatorname{xxxxx}$ & & $\operatorname{xxxxx}$ & & & $\operatorname{xxxxx}$ & \\
\hline Cytheropteron carolinae & & & & & & $\operatorname{xxxxx}$ & $\operatorname{xxxxx}$ & $\operatorname{xxxxx}$ & & & & & & $\operatorname{xxxxx} x$ & $\mathrm{xxxxx}$ & \\
\hline Argilloecia conoidea & & & & LLLLL & LLLLL & $\mathrm{xxxxx}$ & LLLLL & & & $\mathrm{xxxxx}$ & $\mathrm{xxxxx}$ & $\operatorname{xxxxx}$ & $\operatorname{xxxxx}$ & & $\operatorname{xxxxx}$ & \\
\hline Pseudocythere caudata & & LLLLL & ELLLL & $\operatorname{xxxxx}$ & LLLLL & $\operatorname{xxxxx}$ & $\mathrm{xxxxx}$ & $\operatorname{xxxxx}$ & $\mathrm{xxxxx}$ & $\mathrm{xxxxx}$ & $\operatorname{xxxxx}$ & & LLLLL & $\operatorname{xxxxx} \quad x$ & $\operatorname{xxxxx}$ & \\
\hline Baffinicythere howei & & & & & & & & & & & & & & $x \times x \times x$ & & \\
\hline Hemicytherura clathrata & & & & & & & & & & & & & & $\mathrm{xxxxx}$ & & \\
\hline Henryhowella dasyderma & & & & & & & & & & & & $\operatorname{xxxxx}$ & & $\mathrm{xxxxx}$ & & \\
\hline Krithe minima & & & & & & & & $\operatorname{xxxxx}$ & & & $\operatorname{xxxxx}$ & & $\operatorname{xxxxx}$ & $\mathrm{xxxxx}$ & & \\
\hline Haplocytheridea bradii & & & & & & & $\operatorname{xxxxx}$ & & & & & & & $\mathrm{xxxxx}$ & & \\
\hline Cytheropteron pseudoinflatum & & & & & $\mathrm{XxXxX}$ & $\mathrm{xxxxx}$ & & & $\mathrm{xxxxx}$ & $\operatorname{xxxxx}$ & $\mathrm{xxxxx}$ & & $\mathrm{xxxxx}$ & $\operatorname{xxxxx}$ & & \\
\hline Polycope orbicularis & & LLLLL & LLLLL & & LLLLL & $\mathrm{Xxxxx}$ & LLLLL & & & & & LLLLL & LLLLL & $\mathrm{xxxxx}$ & & \\
\hline Paracytherois flexuosum & $\mathrm{xxxxx}$ & $\operatorname{xxxxx}$ & $\mathrm{xxxxx}$ & $\mathrm{xxxxx}$ & & & $\operatorname{xxxxx}$ & & & $\operatorname{xxxxx}$ & & & $\operatorname{xxxxx}$ & LLLLL & & \\
\hline Nannocythere sp. & & & & & & & $\operatorname{xxxxx}$ & $\operatorname{xxxxx}$ & & $\operatorname{xxxxx}$ & $\operatorname{xxxxx}$ & $\mathrm{xxxxx}$ & $\operatorname{xxxxx}$ & & & \\
\hline Bythoceratina scaberrima & & & & & & & $\mathrm{xxxxx}$ & $\operatorname{xxxxx}$ & & & & & $\operatorname{xxxxx}$ & & & \\
\hline Krithe sp. E. & & & & & & & & & & & & $\operatorname{xxxxx}$ & & & & \\
\hline Krithe sp. $F$ & & & & & & & & $\operatorname{xxxxx}$ & & & & LLLLL & & & & \\
\hline Polycope clathrata & & & & & & $\mathrm{xxxxx}$ & & & & & & $\mathrm{xxxxx}$ & & & & \\
\hline Argilloecia cylindrica & & & $\mathrm{xxxxx}$ & & $\mathrm{XXXXX}$ & $\operatorname{xxxxx}$ & LLLLL & & $\operatorname{xxxxx}$ & $\operatorname{xxxxx}$ & LLLLL & $\mathrm{XxXxx}$ & & & & \\
\hline Propontocypris sp. & & & & & & & & & & $\mathrm{xxxxx}$ & & & & & & \\
\hline Microcythere sp. & & & & & & & LLLLL & & & LLLLL & & & & & & \\
\hline Cytheropteron syntomoalatum & & & & & & $\operatorname{xxxxx}$ & $\mathrm{xxxxx}$ & $\operatorname{xxxxx}$ & & $\mathrm{xxxxx}$ & & & & & & \\
\hline Krithe sp. $B$ & & & & & & LLLLL & LLLLL & $\operatorname{xxxxx}$ & $x \times x x x$ & $\operatorname{xxxxx}$ & & & & & & \\
\hline Krithe sp. $C$. & & & & & & & $\operatorname{xxxxx}$ & & $\operatorname{xxxxx}$ & & & & & & & \\
\hline Cytherois pusilla & & & & & & & LLLLL & LLLLL & & & & & & & & \\
\hline Cytheropteron porterae & $\operatorname{xxxxx}$ & & $\operatorname{xxxxx}$ & $\mathrm{xxxxx}$ & $\operatorname{xxxxx}$ & & & $\operatorname{xxxxx}$ & & & & & & & & \\
\hline Acetabulastoma hyperborea & & & & & & & $\operatorname{xxxxx}$ & & & & & & & & & \\
\hline Paijenborchella sp. & & & & & & & $\operatorname{xxxxx}$ & & & & & & & & & \\
\hline Paradoxostoma productum & & & & & & & LLLLL & & & & & & & & & \\
\hline Cytheropteron groenlandicum & & & & & $\operatorname{xxXXX}$ & & $\mathrm{xxxxx}$ & & & & & & & & & \\
\hline Eucytherura delineata & & & & & $\operatorname{xxxxx}$ & $\operatorname{xxxxx}$ & $\mathrm{xxxxx}$ & & & & & & & & & \\
\hline Muellerina abyssicola & & & $\operatorname{xxxxx}$ & LLLLL & LLLLL & & $\mathrm{xxxxX}$ & & & & & & & & & \\
\hline Cytheropteron testudo & & LLLLL & LLLLL & LLLLL & LLLLL & $\operatorname{xxxxx}$ & $\operatorname{xxxxx}$ & & & & & & & & & \\
\hline Cytheropteron pyramidale & $\operatorname{xxxxx}$ & & & & $\mathrm{xxxxx}$ & & $\operatorname{xxxxx}$ & & & & & & & & & \\
\hline Cytheropteron sedovi & & & $\mathrm{xxxxx}$ & $\operatorname{xxxxx}$ & $\mathrm{xxxxx}$ & $\mathrm{xxxxx}$ & & & & & & & & & & \\
\hline Cytheropteron simplex & & & & & $\mathrm{xxxxx}$ & & & & & & & & & & & \\
\hline Krithe sp. D. & & & & & $\mathrm{XxXXX}$ & & & & & & & & & & & \\
\hline Polycope areolata & & & & & $\operatorname{xxxxx}$ & & & & & & & & & & & \\
\hline Cytheropteron arcticum & & & $\operatorname{xxxxx}$ & $\mathrm{xxxxx}$ & $\mathrm{XXXXX}$ & & & & & & & & & & & \\
\hline Cytheropteron inflatum & & & $\operatorname{xxxxx}$ & $\mathrm{xxxxx}$ & $\mathrm{xxxxx}$ & & & & & & & & & & & \\
\hline Thaerocythere crenulata & & & $\operatorname{xxxxx}$ & $\mathrm{xxxxx}$ & $\operatorname{xxxxx}$ & & & & & & & & & & & \\
\hline Cluthia cluthae & & LLLLL & & LLLLL & LLLLL & & & & & & & & & & & \\
\hline Finmarchinella barentzovoensis & & & $\operatorname{xxxxx}$ & & & & & & & & & & & & & \\
\hline Krithe glacialis & & LLLLL & LLLLL & & & & & & & & & & & & & \\
\hline Cytheropteron nodosum & & $\operatorname{xxxxx}$ & & & & & & & & & & & & & & \\
\hline Eucythere sp. $A$. & & $\mathrm{xxxxx}$ & & & & & & & & & & & & & & \\
\hline Rabilimis mirabilis & & $\operatorname{xxxxx}$ & & & & & & & & & & & & & & \\
\hline Cytheropteron neali & $\operatorname{xxxxx}$ & & & & & & & & & & & & & & & \\
\hline Semicytherura affinis & LLLLL & & & & & & & & & & & & & & & \\
\hline
\end{tabular}

\section{DISCUSSION AND CONCLUSIONS}

The most significant result from this study is the pronounced faunal turnover which takes place between 600 and $1100 \mathrm{~m}$, where shelf species are replaced by bathyal and abyssal taxa. The Greenland Sea is characterized by fairly constant temperatures and generally little variation in nutrient levels. Several possible causes exist for the faunal turnover, such as change in temperature salinity or oxygenation at a water mass boundary.

Aagaard (1981) recognised a zone of reduced salinities in the Greenland Sea between 1000 and $1600 \mathrm{~m}$ and Belanger Streeter
(1980) noted that the oxygen minimum zone occurs between 800 and $1200 \mathrm{~m}$. However, although both of these phenomena occur at depths which render it possible to allow one to invoke their agency in causing the faunal turnover, the reductions in salinity and oxygen levels are very small scale.

Dingle \& Lord (1990) identified the water mass boundaries in the Atlantic as a cause of the depth zonation of certain deep sea ostracods. The upper limit of the Greenland Sea Deep Water occurs at $900 \mathrm{~m}$, which correlates with the faunal turnover as shown by the first peak in Figs 3 and 4, and probably exerts 


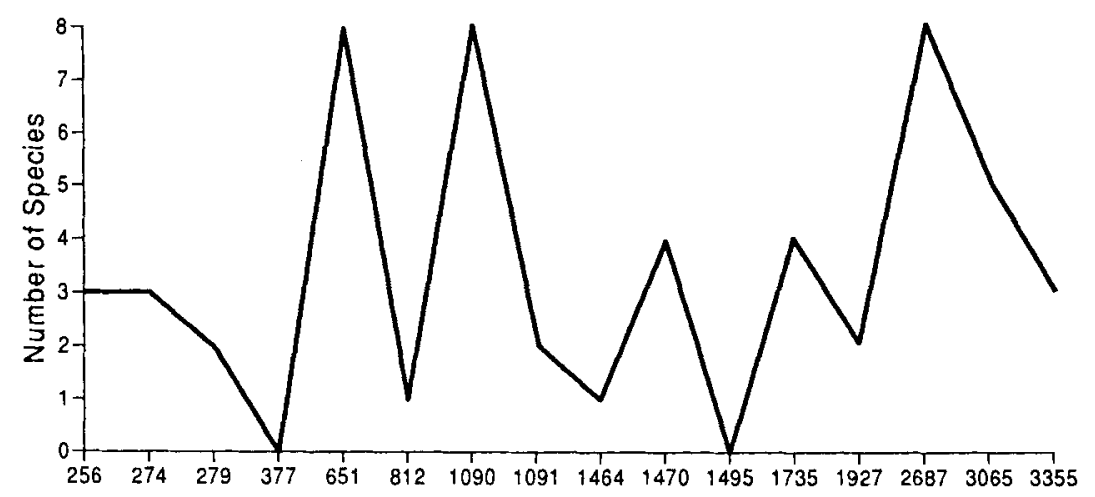

Fig. 3. Graphical representation of the number of species disappearing with depth in the various transects across the Greenland Sea.

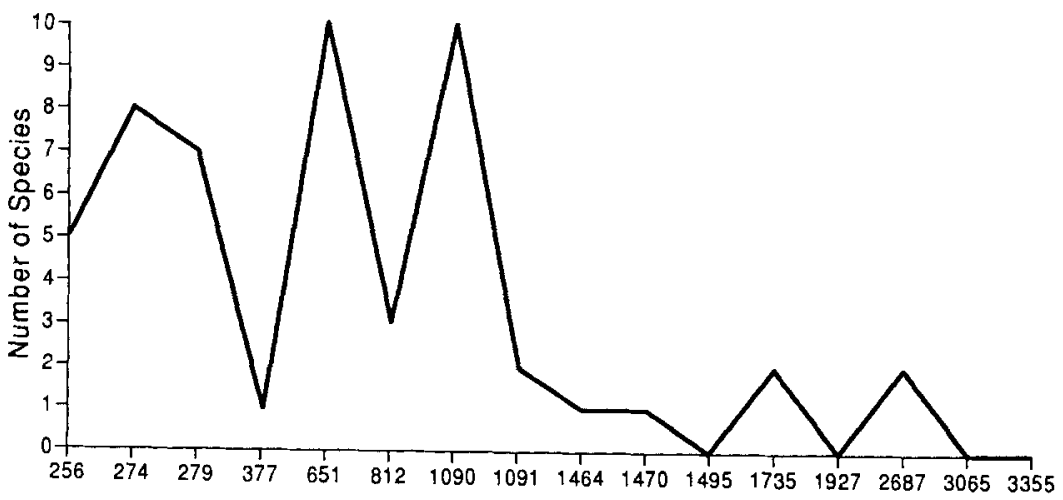

Fig. 4. Graphical representation of the number of species appearing with depth in the various transects across the Greenland Sea.

some influence on the shelf, and on the distribution of the North Atlantic fauna.

Studies such as that of Rosenfeld \& Bein (1978), and Barkham (1985, unpublished MSc Thesis, Aberystwyth) off the coast of Northwest Africa and Cronin (1983) off Cape Hatteras, have recorded a faunal turnover below the shelf break. The East Greenland continental margin is characterized by a very deep continental shelf, with the shelf break occurring at $c .500 \mathrm{~m}$ and, therefore, the change in fauna occurs in a similar position to these other studies (second peak, Figs 3 and 4).

Such Arctic shelf taxa as Thaerocythere crenulata, Muellerina abyssicola and Krithe glacialis have their lower depth limit at $1100 \mathrm{~m}$. Water temperature does not decrease here significantly with depth below $200 \mathrm{~m}$ (see Appendix) so that temperature alone cannot be the sole barrier to downslope migration of species into the deep sea. Because of the absence of an effective thermocline at these latitudes, theoretically they are where we should expect to encounter a 'backdoor' means of entry into the deep sea and it is very likely this route has been of significance in the past and may still be operative today. It is not easy to prove that the High Latitude Doorway hypothesis has been a major route of access into the deep sea, rendered so difficult by the inception of the thermocline in the late Palaeogene (Benson, 1975; Whatley, 1996) and from that time virtually impossible in lower latitudes, but the temperature controlled stenotopic depth distribution differences between Arctic and North Atlantic assemblages of the same species (Table 1) is possible evidence in the case of certain species. Certainly, in the present study, the clear distinction between shelf and bathyal/abyssal taxa in the Greenland Sea demonstrates the significance of the ecological barriers that exist between them.

The deep sea fauna of the Arctic Ocean lacks many of the taxa which are virtually pandemic elsewhere in the world's oceans. As early as 1969 , Benson after examining 'a few samples from the Arctic' was able to state that this area does not have 'a normal deep-water fauna at the present time'. We note the absence from the Greenland Sea of such genera as Bradleya Hornibrook and Poseidonamicus Benson, members of the pandemic deep sea fauna. Also, Coles (pers. comm. 1992) commented that the Krithe spp. from the Greenland Sea '... seem to be distinct from 'true' deep sea North Atlantic faunas further south and in deep sea water areas'.

Joy \& Clark (1977) in their study of the deep water ostracods of the Canadian Basin, recorded three species which are common with the fauna of the Greenland Sea. These are: Henryhowella dasyderma (1351-3193 m), Pseudocythere caudata (1531-3198m) and Polycope punctata (1351-2810m). These authors also described 13 species which were then confined to the Canadian Basin and these figures indicate the importance as a barrier to migration of the Lomonosov Ridge.

More species (at least ten), are common with the fauna described from the Quaternary of the deep Arctic Basin by Cronin et al. (1994). It is not possible to be more precise since neither Krithe nor Polycope are speciated in the latter work. 


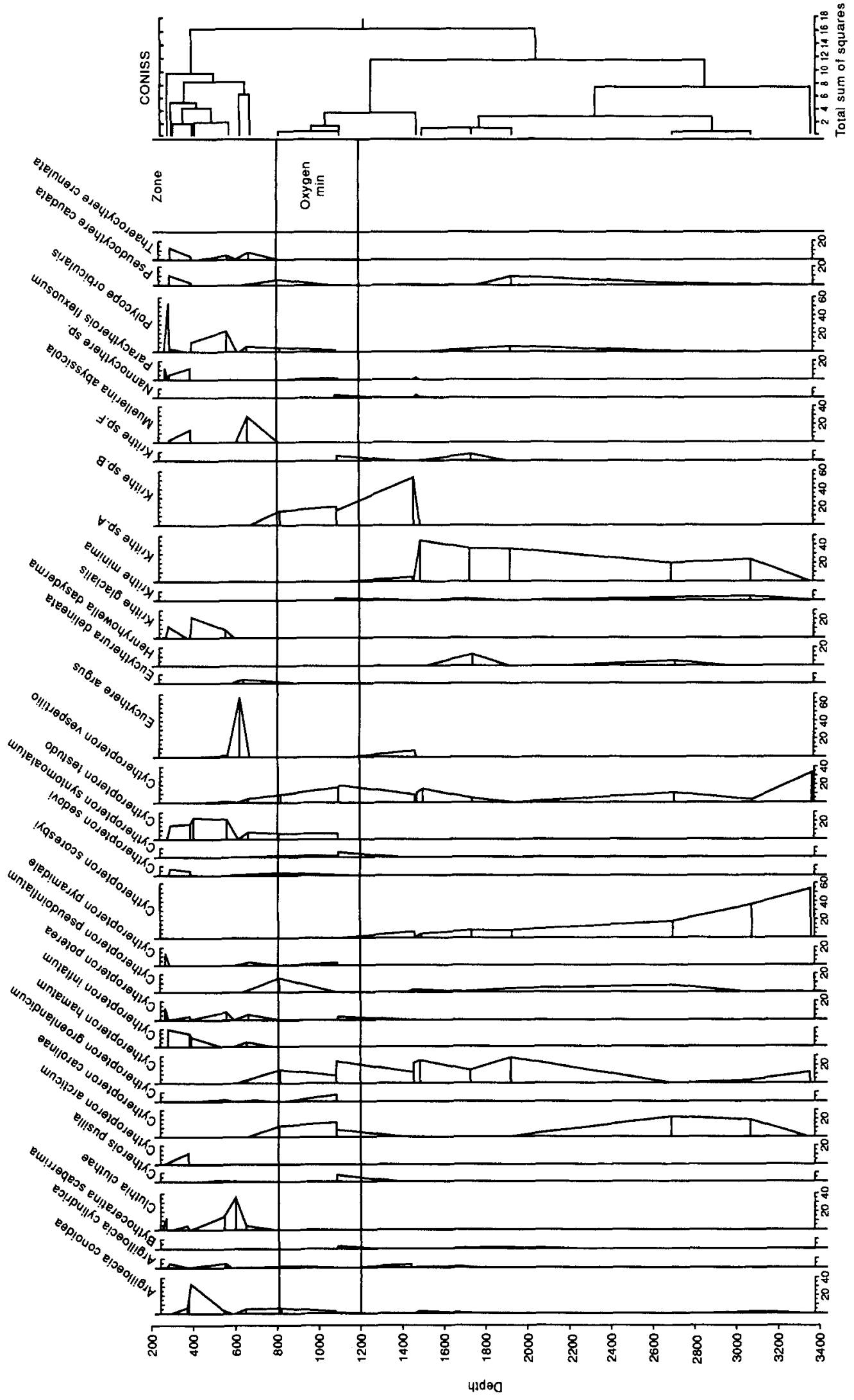



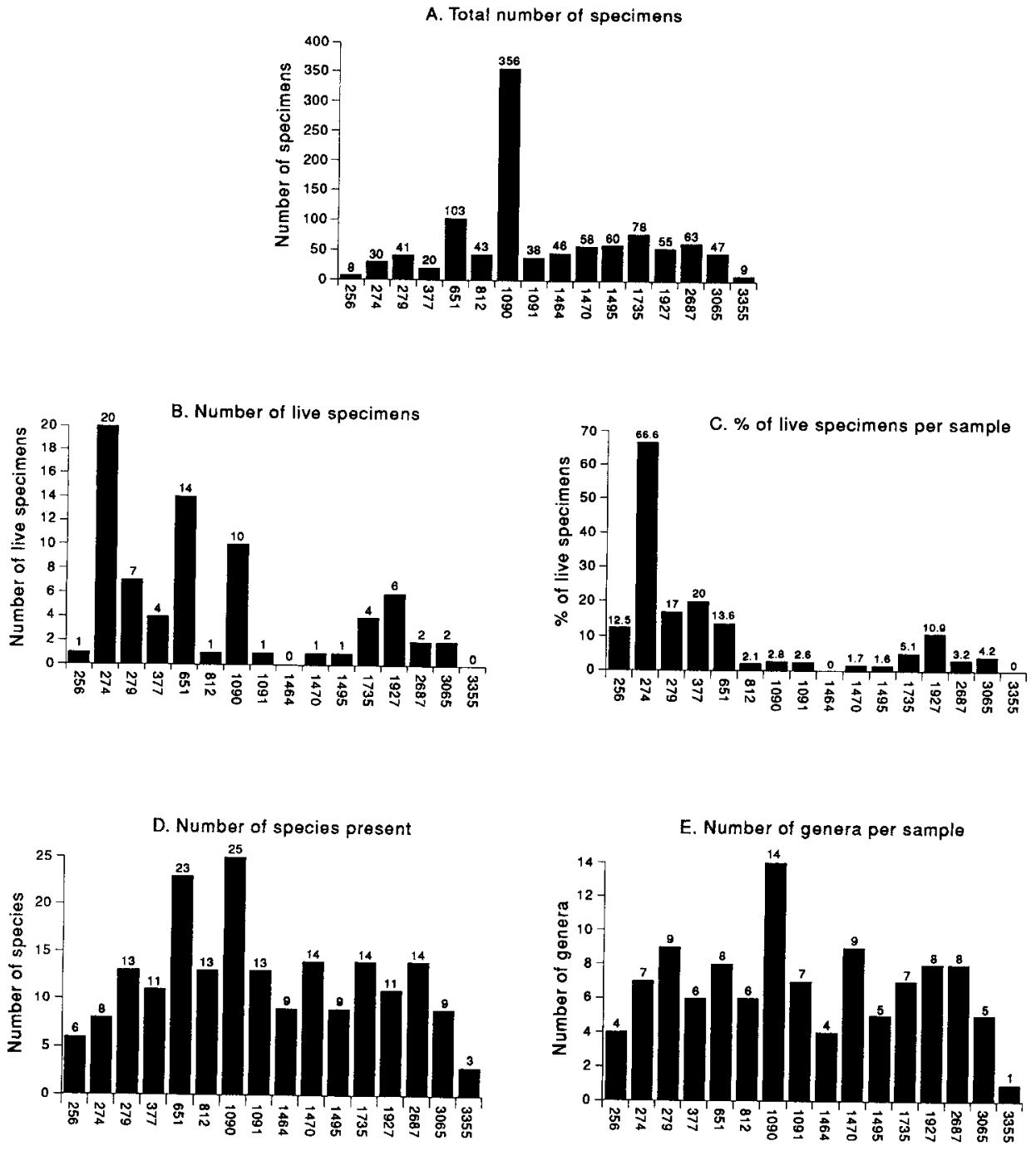

Fig. 6. The total number of specimens, number of live specimens, percentage of live specimens, number of species and number of genera per sample by depth.

Table 4. The number of specimens, number of live species, total number of species, depth in metres per sample in depth order.

\begin{tabular}{lcccc}
\hline Sample & No. spp. & No. live & No. spp. & Depth m \\
\hline 1923 & 8 & 1 & 6 & 256 \\
1916 & 30 & 20 & 8 & 274 \\
1924 & 41 & 7 & 13 & 279 \\
1947 & 25 & 4 & 11 & 377 \\
1948 & 103 & 14 & 23 & 651 \\
1925 & 48 & 1 & 13 & 812 \\
1918 & 356 & 10 & 25 & 1090 \\
1949 & 38 & 1 & 13 & 1091 \\
1951 & 46 & 0 & 9 & 1464 \\
1050 & 58 & 1 & 4 & 1470 \\
1926 & 60 & 1 & 9 & 1495 \\
1927 & 78 & 4 & 14 & 1735 \\
1919 & 50 & 6 & 11 & 1927 \\
1920 & 63 & 2 & 14 & 2687 \\
1921 & 47 & 2 & 9 & 3065 \\
1922 & 9 & 0 & 3 & 3355 \\
\hline
\end{tabular}

These species, all from coretops, are Acetabulastoma arcticum, Bythoceratina scaberrima, Cytheropteron alatum, C. carolinae, C. hamatum, Henryhowella asperrima, Krithe spp., Polycope spp., Pseudocythere caudata.

Table C of Cronin et al. (1994) shows very clearly the important difference between the characteristic ostracods of the Arctic deep ocean basin and those of the Greenland Sea. This very clearly shows the extent to which the Greenland Sea fauna is not typically High Arctic in character and that it represents a Low Arctic fauna with strong connections to the faunas of the Norwegian Sea and to the northern North Atlantic.

\section{ACKNOWLEDGEMENTS}

The authors wish to thank Dr Caroline Maybury who has made a number of suggestions greatly improving the manuscript. We are indebted to Dr R. Whittington who collected and preserved the samples and to Dr H. Grobe for permission to study and publish on the material. 

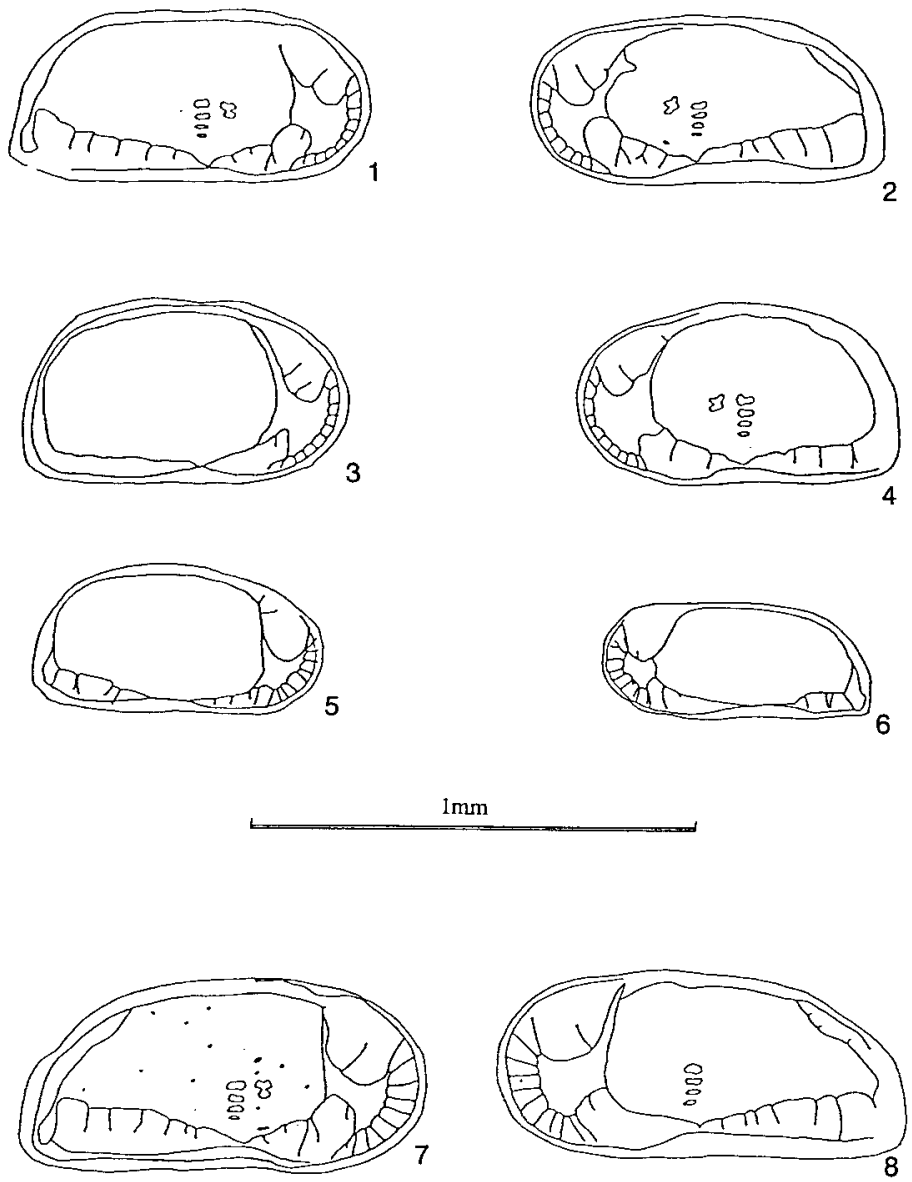

Fig. 7. Projectina drawings of Krithe spp. (all internal views). fig. 1, $K$. glacialis, male LV, ME/12/T; fig. 2, $K$. glacialis, male RV, ME/12/T; fig. 3, $K$. glacialis, female LV, ME/12/P2; fig. 4, $K$. glacialis, female RV, ME/12/P3; fig. 5, $K$. minima, female LV, ME/13/T; fig. 6, $K$. minima, male RV, ME/13/ P1; fig. 7, $K$. sp. A, male LV, ME/14/T; fig. 8, $K$. sp. A, male RV, ME/14/P1.

\section{APPENDIX}

A synopsis of the location, depth and environmental data of the sampling localities.

\begin{tabular}{lllll}
\hline Stn & Coordinates (Lat/Long) & Location & Depth & Sediment \\
\hline 1916 & $74^{\circ} 48.89^{\prime} \mathrm{N} ; 18^{\circ} 43.75^{\prime} \mathrm{W}$ & Fjord mouth & $274 \mathrm{~m}$ & Clay \\
1918 & $75^{\circ} 00.00^{\prime} \mathrm{N} ; 12^{\circ} 28.06^{\prime} \mathrm{W}$ & Upper slope & $1090 \mathrm{~m}$ & Silty clay dropstones \\
1919 & $74^{\circ} 59.76^{\prime} \mathrm{N}: 11^{\circ} 51.55^{\prime} \mathrm{W}$ & Continental slope & $1927 \mathrm{~m}$ & Sandy clay \\
1920 & $74^{\circ} 59.88^{\prime} \mathrm{N} ; 11^{\circ} 05.60 \mathrm{~W}$ & Lower slope & $2687 \mathrm{~m}$ & Clay planctonic forams \\
1921 & $75^{\circ} 00.22 \mathrm{~N} ; 10^{\circ} 36.26^{\prime} \mathrm{W}$ & Lower slope & $3063 \mathrm{~m}$ & Clay planctonic forams \\
1922 & $74^{\circ} 59.92^{\prime} \mathrm{N} ; 20^{\circ} 29.99^{\prime} \mathrm{W}$ & Continental rise & $3355 \mathrm{~m}$ & Clay planctonic forams \\
1923 & $71^{\circ} 28.82^{\prime} \mathrm{N} ; 20^{\circ} 29.99^{\prime} \mathrm{W}$ & Shelf & $256 \mathrm{~m}$ & Sandy clay with ice rafted debris \\
1924 & $71^{\circ} 29.95^{\prime} \mathrm{N} ; 19^{\circ} 11.55^{\prime} \mathrm{W}$ & Shelf & $279 \mathrm{~m}$ & Sandy clay with ice rafted debris \\
1925 & $71^{\circ} 29.93^{\prime} \mathrm{N} ; 18^{\circ} 43.29^{\prime} \mathrm{W}$ & Upper slope & $812 \mathrm{~m}$ & Sandy clay with ice rafted debris \\
1926 & $71^{\circ} 29.47^{\prime} \mathrm{N} ; 18^{\circ} 16.58^{\prime} \mathrm{W}$ & Continental slope & $1419 \mathrm{~m}$ & Silty clay \\
1927 & $71^{\circ} 29.78^{\prime} \mathrm{N} ; 17^{\circ} 08.81^{\prime} \mathrm{W}$ & Mid-slope & $1735 \mathrm{~m}$ & Clay \\
1947 & $69^{\circ} 16.34^{\prime} \mathrm{N} ; 21^{\circ} 46.41^{\prime} \mathrm{W}$ & Shelf & $377 \mathrm{~m}$ & Sandy clay with ice rafted debris \\
1948 & $69^{\circ} 04.05^{\prime} \mathrm{N} ; 21^{\circ} 17.03^{\prime} \mathrm{W}$ & Upper slope & $651 \mathrm{~m}$ & Sandy clay with ice rafted debris \\
1949 & $68^{\circ} 59.65^{\prime} \mathrm{N} ; 21^{\circ} 10.08 \mathrm{~W}$ & Upper slope & $1091 \mathrm{~m}$ & Clay with ice rafted debris \\
1950 & $68^{\circ} 53.62^{\prime} \mathrm{N} ; 20^{\circ} 58.57^{\prime} \mathrm{W}$ & Continental slope & $1470 \mathrm{~m}$ & Clay with ice rafted debris \\
1951 & $68^{\circ} 50.03^{\prime} \mathrm{N} ; 20^{\circ} 49.72^{\prime} \mathrm{W}$ & Continental slope & $1464 \mathrm{~m}$ & Clay with ice rafted debris \\
\hline
\end{tabular}



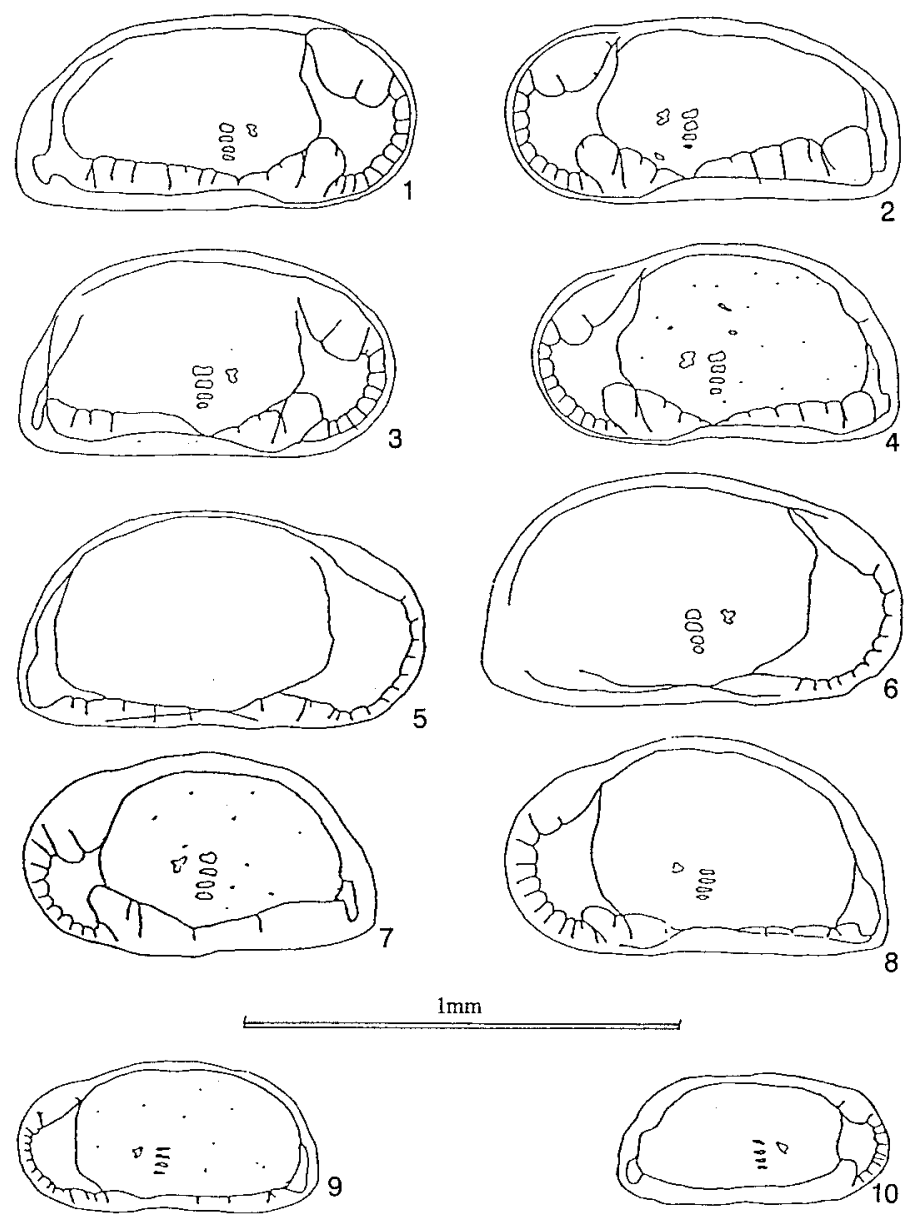

Fig. 8. Projectina drawings of Krithe spp. (all internal views). fig. 1, $K$. sp. B, male LV, ME/15/T; fig. 2, $K$. sp. B, male RV, ME/15/PI; fig. 3, $K$. sp. B, female LV, ME/15/P2; fig. 4, $K$. sp. B, female RV, ME/15/P3; fig. 5, $K$. sp. C, female LV, ME/16/T; fig. 6, $K$. sp. C, female LV, ME/16/P1; fig. 7, $K$. sp. D, female RV, ME/17/T; fig. 9, $K$. sp. E, female RV, ME/18/T; fig. 9, $K$. sp. F, female RV, ME/19/T; fig. 10, $K$. sp. F, male LV, ME/19/P1.

Some stations have temperature and salinity data:

\begin{tabular}{lll}
\hline Station & Salinity \% & Temperature ${ }^{\circ} \mathrm{C}$ \\
\hline 1921 & 34.9 & -1.0 \\
1927 & 34.9 & -0.75 \\
1949 & 34.9 & -0.25 \\
1951 & 34.9 & -060 \\
\hline
\end{tabular}

Manuscript received May 1995

\section{Manuscript accepted May 1996}

\section{REFERENCES}

Aagaard, K. 1968. Temperature variations in the Greenland Sea deepwater. Deep Sea Research, 15: 281-296.

Aagaard, K. 1981. On the deep circulation in the Arctic Ocean. Deep Sea Research, 28A(3): 251-268.

Aagaard, K. 1982. Inflow from the Atlantic Ocean to the Polar Basin. In Rey, L. (Ed.). The Arctic Ocean. Macmillan London, 69-81.
Aagaard, K. \& Coachman, L. K. 1969. The East Greenland Current North of the Denmark Strait: Part II. Arctic, 21(4): 267-290.

Aagaard, K., Coachman, L. K. \& Carmack, E. 1981. On the halocline of the Arctic Ocean. Deep Sea Research, 28A(6): 529-545.

Aagaard, K., Swift, J. H., \& Carmack, E. 1985. Thermohaline circulation in the Arctic Mediterranean Seas. Journal of Geophysical Research, 90(C3): 4833-4846.

Belanger, P. E. \& Streeter, S. S. 1980. Distribution and ecology of benthonic Foraminifera in the Norwegian-Greenland Sea. Marine Micropalaeontology, 5: 401-428.

Benson, R. H. 1975. The origin of the psychrosphere as recorded in changes in deep-sea ostracod assemblages. Lethata, 8: 69-83. 
Benson, R. H., DelGrosso, R. M. \& Steineck, P. L. 1983. Ostracode distribution and bifacies, Newfoundland continental slope and rise. Micropaleontology, 29(4): 430-453.

Bourke, R. H., Newton, J. L., Paquette, R. G. \& Tunnicliffe, M. D. 1987. Circulation and water masses of the East Greenland Shelf. Journal of Geophysical Research, 92(C7): 6729-6740.

Brady, G. S. 1866. On new or imperfectly known species of marine Ostracoda. Transactions of the Zoological Society of London, 5: 359393.

Brady, G. S. 1868. Contributions to the study of Entomostraca 1. Ostracoda from the Arctic and Scandinavian seas. Annals and Magazine of Natural History, ser. 4(2): 30-35.

Brady, G. S. 1870 . Contributions to the study of Entomostraca V. Recent Ostracoda from the Gulf of St. Lawrence. Annals and Magazine of Natural History, ser. 4(6): 450-455.

Brady, G. S. 1878. Notes on the Ostracoda. Narrative of a Voyage to the Polar seas, 1875-76, in H.M.S. Alert and H.M.S. Discovery. London 2: $253-255$.

Brady, G. S. \& Norman, A. M. 1889. A Monograph of the Marine and Freshwater Ostracods of the N. Atlantic and of NW Europe. Section 1; Podocopida. Scientific Transactions of the Royal Dublin Society, 4 (Series 2): 63-270.

Brady, G. S., Crosskey, H. W. \& Robertson, D. 1874. A Monograph of the Post-Tertiary Entomostraca of Scotland, including species from England and Ireland. Palaeontographical Society, London.

Brouwers, E. M., Jorgensen, N. O., \& Cronin, T. M. 1991. Climatic significance of the ostracode fauna from the Pliocene Kap Kobenhavn Formation, north Greenland. Micropaleontology, 37(3): 245-267.

Coles, G. 1990. A comparison of the evolution, diversity and composition of the Cainozoic Ostracoda in the deep water Atlantic and shallow water environments of North America and Europe. In Whatley, R. C. \& Maybury, C. (Eds). Ostracoda and Global Events, 71-86. Chapman \& Hall, London.

Coles, G., Ayress, M. \& Whatley, R.C. 1990. A comparison of North Atlantic and Pacific Cainozoic deep-sea Ostracoda. In Whatley, R. C. \& Maybury, C. (Eds), Ostracoda and Global Events, 287-305. Chapman \& Hall, London.

Coles, G. P., Whatley, R. C. \& Moguilevsky, A. 1994 The ostracod genus Krithe from the Tertiary and Quaternary of the North Atlantic. Palaeontology, 37(1): 71-120.

Cronin, T. M. 1979. Late Pleistocene marginal marine ostracodes from the southeastern Atlantic Coastal Plain and their palaeoenvironmental implications. Géographie physique Quaternaire, 33(2): 121-173.

Cronin, T. M. 1980. Paleoclimatic implications of late Pleistocene marine ostracods from the St. Lawrence Lowlands. Micropaleontology, 27(4): 384-418.

Cronin, T. M. 1983. Bathyal ostracodes from the Florida-Hatteras Slope, the Straits of Florida and the Blake Plateau. Marine Micropalaeontology, 8: 89-119.

Cronin, T. M. 1991. Late Neogene marine Ostracoda from Tjornes, Iceland. Journal of Paleontology, 65(5): 767-789.

Cronin, T. M., Holtz, T. R. \& Whatley, R. C. (1994). Quaternary paleoceanography of the deep Arctic Ocean based on quantitative analysis of Ostracoda. Marine Geology, 119: 305-332.

Dingle, R. V. \& Lord, A. R. 1990. Benthic ostracods and deep water masses in the Atlantic Ocean. Palaeogeography, Palaeoclimatology, Palaeoecology, 80: 213-235.

Hartmann, G. 1992. Zur Kenntnis der rezenten und subfossilen Ostracoden des Liefdefjords (Nordspitzbergen, Svålbard) I. Teil. Mit einer Tabelle subfossil nachgewiesener. Foraminifera. Ergebnisse der Geowissenschaftlichen Spitzbergen-Expedition 1990. Mitteilungen Hamburg zoologisches Museum und Institut, 89: 181-225.

Hartmann, G. 1993. Zur Kenntnis der rezenten und subfossilien Ostracoden des Liefdefjords (Nordspitzbergen, Svålbard) II. Teil. Ergebnisse der Geowissenschaftlichen Spitzbergen - Expedition 1991.Mitteilungen Hamburg zoologisches Museum und Institut, 90: $181-225$.

Hartmann, G. 1994. Zur Kenntnis der rezenten und subfossilien Ostracoden des Liefdefjords (Nordspitzbergen, Svålbard) Nachtrag. Ergebnisse der Geowissenschaftlichen Spitzbergen - Expedition 1992. Mitteilungen Hamburg zoologisches Museum und Institut, 91: 81-88.

Hazel, J. E. 1967. Classification and distribution of the Recent
Hemicytheridae and Trachyleberididae (Ostracoda) off N.E., N. America. United States Geological Survey, Professional Paper, No. 564: $1-49$

Hazel, J. E. 1970. Ostracode Zoogeography in the Southern Nova Scotian and Northern Virginian Faunal provinces. USGS Professional Paper, No. 529-E: 1-21.

Joy, J. A. \& Clark, D. K. 1977. The distribution, ecology and systematics of the benthic Ostracoda of the Central Arctic Ocean. Micropaleontology 23(2): 129-154.

Lord, A. R. 1980. Weichselian (Late Quaternary) ostracods from the Sandness Clay, Norway. Geological Magazine, 117(3): 227-242.

Maddocks, R. F. \& Steineck, P. L. 1987. Ostracoda from experimental wood-island habitats in the deep sea. Micropaleontology, 33: 318-355.

Neale, J. W. \& Howe, H. V. 1975. The marine Ostracoda of Russian Harbour, Novaya Zemlya and other high latitude faunas. Bulletins of American Paleontology. Ithaca, New York, 65(282): 381-431.

Norman, A. M. 1877 . Notes on the marine Crustacea, Ostracoda of Norway. Annals and Magazine of Natural History Science, 6: 108-121.

Penney, D. N. 1989. Recent shallow marine Ostracoda of the Ikerssuak (Bredefjord) District, Southwest Greenland. Journal of Micropalaeontology, 8(1): 55-75

Peterson, W. H. \& Rooth, C. G. H. 1976. Formation and exchange of deep water in the Greenland and Norwegian Seas. Deep Sea Research, 23: 273-283

Peypouquet, J.-P. 1975. Les variations des caractères morphologiques internes chez les ostracodes des genres Krithe et Parakrithe: relation possible avec le teneur en $\mathrm{O} 2$ dissous dans l'eau. Bulletin de l'Institut de Géologie du Bassin d'Aquitaine, 17: 81-88.

Peypouquet, J.-P. 1977. Les ostracodes et la connaisance des paléomilieux profonds. Application au Cénozoic de l'Atlantique Nord-Oriental, Université de Bordeaux, 433pp.

Peypouquet, J.-P. 1979. Ostracodes et paléoenvironements. Méthodologie et application aux domaines profonds du Cénozoique. Bulletin du Bureau de Recherches Géologiques et Minières, 2nd series, 4: 3-79.

Rosenfeld, A. \& Bein, A. 1978. A preliminary note on Recent ostracodes from shelf to rise sediments off Northwest Africa. Meteor Forschungs Ergebnisse Reihe C, 29: 14-20.

Sars, G. O. 1909. Report of the 2nd Norwegian Arctic Expedition 'Fram' 1898-1902, III(18): 1-47

Skogsberg, T. 1920. Studies on marine ostracods. Zoologiska Bidrag Uppsala (Suppl.), I: 1-784.

Solheim, A, Elverhoi, A, Anderson, E. S. \& Jahre, H. 1991. Marine geological/geophysical cruise on the Western Svalbard Margin, 1900. Cruise Report. Norsk Polarinstitut Rappotserie, N.R. 69, Oslo.

Steineck, P. L., Maddocks, R. F., Turner, R. D., Coles, G. \& Whatley, R. C. 1990. Xylophile Ostracoda in the deep sea. In Whatley, R. C. Maybury, C. (Eds). Ostracoda and Global Events. 307-319, Chapman \& Hall, London.

Stephensen, K. 1913. Gronlands Krebsdyr og Pycnogonider (Conspectus Crustaceorum et Pycnogonidorum Groenlandiae). Meddelelser om Gronland, 22: 1-479.

Stephensen, K. 1939. Marine Ostracoda and Cladophora. The Zoology of Iceland III (32): 1-19.

Van Harten, D. 1994. Deep sea hydrothermal vent eucytherine Ostracoda. The enigma of the pore cluster and the paradox of the hinge. In: McKenzie, K. G. \& Jones, P. J. (Eds). Ostracoda in the Earth and Life Sciences, 571-580. Proc. 11th Int. Symp. Ostracoda, Warrnambool, Victoria, Australia 1991

Vogt, P. R., Perry, R. K., Feden, R. H., Fleming, H. S. \& Cherkis, N. Z. 1981. The Greenland Norwegian Sea and Iceland Environment: Geology and Geophysics. In Nairn, A. E. M. (Ed.). The Ocean Basins and Margins. Vol. 5, The Arctic Ocean. Plenum.

Whatley, R. C. 1982. Littoral and sub-littoral Ostracoda from Sisimuit, West Greenland. In Fox, A. D and Stroud, D. A. (Eds). Report of the 1979 Greenland White-Fronted Goose Study Expedition to Eqalungmint Nunal, West Greenland, University of Wales Press, 700pp.

Whatley, R. C. 1993. Ostracoda as biostratigraphical indices in Cainozoic deep-sea sequences. In Kidd, R. \& Hailwood, E. (Eds). High Resolution Stratigraphy, 70: 155-167. Geological Society, London.

Whatley, R. C. 1996. The bonds unloosed: The contribution of Ostracoda to our understanding of deep sea cvents and processes. In 
Moguilevsky, A. \& Whatley, R. C. (Eds). Microfossils and Oceanic Environments. University of Wales, Aberystwyth Press.

Whatley R. C. \& Coles, G. 1987. The late Miocene to Quaternary Ostracoda of Leg. 94, Deep Sea Drilling Project. Revista Española de Micropaleontologia, 19: 33-97.

Whatley, R. C. \& Coles, G. 1990. Global change and the biostratigraphy of North Atlantic Cainozoic deep water Ostracoda. Journal of Micropalaeontology, 9: 119-132.

Whatley, R. C. \& Eynon, M. P. 1996. Four new Arctic deepwater ostracod species from East Greenland. In Keen, M. C. (Ed.)
Proceedings of the 2nd European Ostracodologists Meeting, University of Glasgow, UK, 23-27 July 1993, 195-200.

Whatley, R. C., Eynon, M. P. \& Moguilevsky, A. (1996). Recent Ostracoda of the Scoresby Sund Fjord system, East Greenland. Revista Española de Micropaleontologia, 28(2): 5-23.

Whatley, R. C. \& Zhao, Q. 1993. The Krithe problem; a case history of the distribution of Krithe and Parakrithe (Crustacea, Ostracoda) in the South China Sea. Palaeogeography, Palaeoclimatology, Palaeoecology, 103: 281-297.

Worthington, L. V. 1970 The Norwegian Sea as a Mediterranean Basin. Deep Sea Research, 17: 77-84. 